Summer 8-22-2020

\title{
The Effect of Medication Reconciliation Timeout on Patient Safety: An Evidence-Based Project
}

Renante Dizon

University of St. Augustine for Health Sciences, r.dizon@usa.edu

DOI: https://doi.org/10.46409/sr.RWLY6082

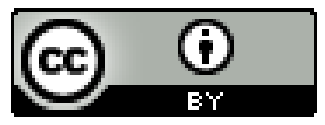

This work is licensed under a Creative Commons Attribution 4.0 License.

Follow this and additional works at: https://soar.usa.edu/scholprojects

Part of the Critical Care Nursing Commons, Geriatric Nursing Commons, and the Life Sciences Commons

\section{Recommended Citation}

Dizon, R. (2020). The Effect of Medication Reconciliation Timeout on Patient Safety: An Evidence-Based Project. [Doctoral project, University of St Augustine for Health Sciences]. SOAR @ USA: Student Scholarly Projects Collection. https://doi.org/10.46409/sr.RWLY6082

This Scholarly Project is brought to you for free and open access by the Student Research at SOAR @ USA. It has been accepted for inclusion in Student Scholarly Projects by an authorized administrator of SOAR @ USA. For more information, please contact soar@usa.edu, erobinson@usa.edu. 
The Effect of Medication Reconciliation Timeout on Patient

Safety: An Evidence-Based Project

Renante Dizon, MSN, RN

School of Nursing, University of St. Augustine for Health Sciences

This Manuscript Partially Fulfills the Requirements for the

Doctor of Nursing Practice Program and is Approved by:

Dr. Douglas M. Turner, PhD, DNP, RN, CNE, NE-BC, NEA-BC

Dr. Andrya Rivera-Burciaga, DNP, APRN, FNP-BC, ACHPN

Dr. Pamela Gobina, PharmD, MBA

Date of Final Approval: August 5, 2020 


\section{University of St. Augustine for Health Sciences \\ DNP Scholarly Project \\ Signature Form}

\begin{tabular}{|c|c|c|c|}
\hline $\begin{array}{l}\text { Student Last Name: } \\
\text { Dizon }\end{array}$ & & First Name: & $\begin{array}{c}\text { Middle Initial: } \\
\text { B }\end{array}$ \\
\hline \multicolumn{4}{|l|}{$\begin{array}{l}\text { E-mail: } \\
\text { r.dizon@usa.edu }\end{array}$} \\
\hline \multicolumn{4}{|l|}{ Title of DNP Project: } \\
\hline \multicolumn{4}{|c|}{ The Effect of Medication Reconciliation Timeout on Patient Safety: An Evidence- Based Project } \\
\hline \multicolumn{4}{|c|}{$\begin{array}{l}\text { I have reviewed and approved this final written DNP Project. My typed name below serves as my electronic } \\
\text { signature. }\end{array}$} \\
\hline Faculty/Preceptor Typed Name & $\begin{array}{l}\text { Electronic } \\
\text { Signature }\end{array}$ & Email Address & Date \\
\hline $\begin{array}{l}\text { DNP Project Primary Faculty: } \\
\text { Douglas M. Turner, PhD, DNP }\end{array}$ & Douglas Turner & dturner@usa.edu & $08 / 05 / 2020$ \\
\hline $\begin{array}{l}\text { DNP Project Preceptor: } \\
\text { Pamela Gobina }\end{array}$ & P. Gobina & pamela.lawani@gmail.com & $8 / 4 / 2020$ \\
\hline $\begin{array}{l}\text { DNP Project Preceptor: } \\
\text { Andrya R. Rivera-Burciaga }\end{array}$ & 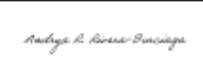 & aburciaga76@gmail.com & $8 / 5 / 2020$ \\
\hline
\end{tabular}




\begin{abstract}
Practice Problem: There was a report of a high rate of medication errors from inaccurate medication reconciliation during admission to a local hospital in South Texas. The medication error rate was $14.88 \%$ on 20 reviewed charts, and $85 \%$ of all evaluated charts contained at least one medication discrepancy.
\end{abstract}

PICOT: This evidence-based, system-change project was guided by the following PICOT question: For nurses administering medication in a long-term acute care hospital, does the implementation of Medication Reconciliation Timeout Process (MRTP) decrease the medication errors, compared to the usual medication practice, in one month?

Evidence: Thirteen pertinent studies recommended the use of a combination of checklists and the timeout process to see a reduction in the number of medical errors and improvements in performance and safety.

Intervention: The evidence-based intervention utilized MRTP with a checklist while performing medication reconciliation during admission. Two nurses checked the medication reconciliation for accuracy and completeness by comparing the medication list against transferring facility to physician's admission orders.

Outcome: The outcome of the project after the evidence-based intervention was a medication error rate of $3.77 \%$, which was a significant reduction from $14.88 \%$.

Conclusion: The implementation of MRTP resulted in an $11.11 \%$ decrease in medication errors within four weeks in a long-term acute care facility. 
The Effect of Medication Reconciliation Timeout on Patient Safety

Medication safety was at the core of the Joint Commission's National Patient Safety

Goals (Joint Commission, 2015). Numerous studies support the concept that improved medication reconciliation reduces medication errors and adverse drug events. Poor communication of medical information can result in medication errors, especially when patients move frequently from diverse health care settings (Frydenberg \& Brekke, 2012). The transition of care leaves an avenue for medication discrepancies when incomplete and inaccurate information is relayed between the health care team and patients which are errors that could be prevented with better communication among health care workers.

The purpose of this Doctor of Nursing (DNP) project was to improve communication among the healthcare team by implementing best-practice principles in medication reconciliation. This paper includes the discussion of the significance of practice problems, the Population Intervention Comparison Time (PICOT) question, theoretical framework, synthesis of the reviewed literature, practice recommendation, and project settings. It also outlines the project mission, vision, project plan, evaluation, dissemination. The paper ends with a conclusion that demonstrated the reduction of the medication error rates after implementing the evidencebased intervention.

\section{Significance of the Practice Problem}

Medication errors can result in severe patient injury or death (Aldhafeeri \& Alamatrouk, 2019). The different types of medication errors and the frequency of such errors vary substantially, depending on the care settings (Bates \& Slight, 2014). Medication errors have rarely been a problem in areas like obstetrics, where medications have been generally avoided (Bates \& Slight, 2014). However, errors have been much more frequent in intensive care units, 
where patients received an average of 25 medications daily (Bates \& Slight, 2014). When medication errors result in harm, it is called an adverse drug event (Bates \& Slight, 2014).

Medication errors have had significant health and economic consequences (Chen et al., 2019). The errors affected the essential aspects of morbidity, mortality, and health care costs (Hughes, \& Blegen, 2008). About 7,000 to 9,000 people have died from medication errors every year in the United States (Tariq \& Scherbak, 2019). Worldwide, the costs of medication errors have been estimated at \$42 billion a year (World Health Organization, 2017). Since medication errors have occurred globally, national and international safety campaigns were and continue to be necessary (Dellabarca, 2019).

The instances of medication error incidents, and variation of such accidents, increased over the past several months in the chosen facility (Cornerstone Healthcare Group, 2019). The facility's medication error rate was $0.30 \%$, with a total of 115 occurrences for 2019 . The rate for adverse drug reaction was $0.2 \%$, which consisted of one occurrence in June 2019 (Cornerstone Healthcare Group, 2019). During the initial interview, the director of the pharmacy verbalized that evidence-based project was needed in the area of medication reconciliation and said that improper medication reconciliation would result in increased medication errors and variances (P. Gobina, personal communication, September 27, 2019).

\section{Framework of the Problem}

Rogers's Diffusion of Innovations Theory (Kaminski, 2011) was the theoretical framework that drove the reduction of medication errors in the chosen facility with the implementation of a Medication Reconciliation Timeout Process (MRTP). Rogers's Diffusion of Innovation Theory described the process as something that occurred when people adopted a new intervention, idea, practice, product, and philosophy (Kaminski, 2011). A person must recognize 
the idea, behavior, or intervention as new or innovative to facilitate diffusion (LaMorte, 2019). Rogers differentiated five categories of innovation adopters: innovators, early adopters, early majority, late majority, and laggards (Kaminski, 2011). Over time, the person adopts the new idea, intervention, or practice. Adoption signified that a person had executed something differently from what had previously been practiced (LaMorte, 2019).

Rogers's Theory of Diffusion of Innovation (Kaminski, 2011) applied to the project in two key areas. First, the intervention of MRTP needed to be communicated to the staff nurses as a new practice along with its purpose: to reduce medication errors. In addition, Rogers's categories of innovation adopters were used to identify the nurses on staff who would serve as facilitators and barriers to adoption of the intervention and to move them to achieve desired project outcomes.

Rogers's Theory of Diffusion of Innovation connected the process of adopting change to the individual's perception of a new practice (Tariq, 2019). The initiation and implementation of "timeout" during medication reconciliation was a new best practice in the facility, and the decision to adopt it defined innovation. The goal was to utilize new best practice principles to ultimately reduce medication errors. This project applied the checklist tool created explicitly for optimal medication reconciliation.

\section{Scholarly Question}

The PICOT question for the change project was: For nurses administering medication in long-term acute care hospital (P), does the implementation of Medication Reconciliation Time out Process (I) compared to the usual medication practice $(\mathrm{C})$ decrease the medication errors $(\mathrm{O})$ in one month (T)? The population of the project was nurses who administered medications at the hospital. The nurses provided specialized care to the patients in intensive care, telemetry, and 
medical-surgical units. The facility's nurses categorized their professional backgrounds as licensed vocational nurses and registered nurses.

The intervention proposed in this paper demonstrated medication reconciliation by utilizing MRTP. Inaccurate medication reconciliation had led to medication errors that consequently caused increased morbidity, mortality, and healthcare costs (Kraus, Murphy, \& Pontiggia, 2017). Proper medication reconciliation reduced medication errors. The desired outcome of the project was a $10 \%$ or more reduction in the medication errors, along with an $80 \%$ or higher staff compliance rate with the MRTP.

\section{Literature Search Strategy}

The purpose of the search process was to conduct a comprehensive review of the literature regarding the implementation of the MRTP to reduce medication errors in a long-term acute care hospital. A systematic literature search utilized the following University of St. Augustine Library databases: The Cumulative Index to Nursing and Allied Health Literature (CINAHL), PubMed, and ProQuest COMPLETE. The search strings /keywords were timeout OR medication reconciliation checklist. The literature search was limited to "full text only" articles published from 2014 to 2019.

\section{Literature Search Results and Evaluation}

The CINAHL database search yielded 54 articles, PubMed 100 articles, and ProQuest COMPLETE 116,290 citations. After limiting the search to range from 2014 to 2019 to include the most current data on current best- practice, 116,444 articles remained. Inclusion and exclusion criteria were applied to narrow the search. Exclusion criteria were non-human, and pediatric population. Furthermore, the inclusions criteria were English language articles, scholarly journals, articles with abstracts, full text, peer-reviewed articles and those addressing 
patient safety. An inspection of the abstracts and titles resulted in the elimination of 16,251 articles not suited for the PICOT question. The resulting 193 articles were scrutinized, which resulted in 173 citations. Articles were manually sorted and underwent a full text screening. Additional exclusion was based on duplication of seven articles, which were informational, rather than being study-based reports, and articles not related to the PICOT question. After conducting the search strategy and utilizing the PRISMA model, 13 articles were included in the proposed project. See Figure 1 for the PRISMA Diagram.

\section{Medication Reconciliation Timeout Process}

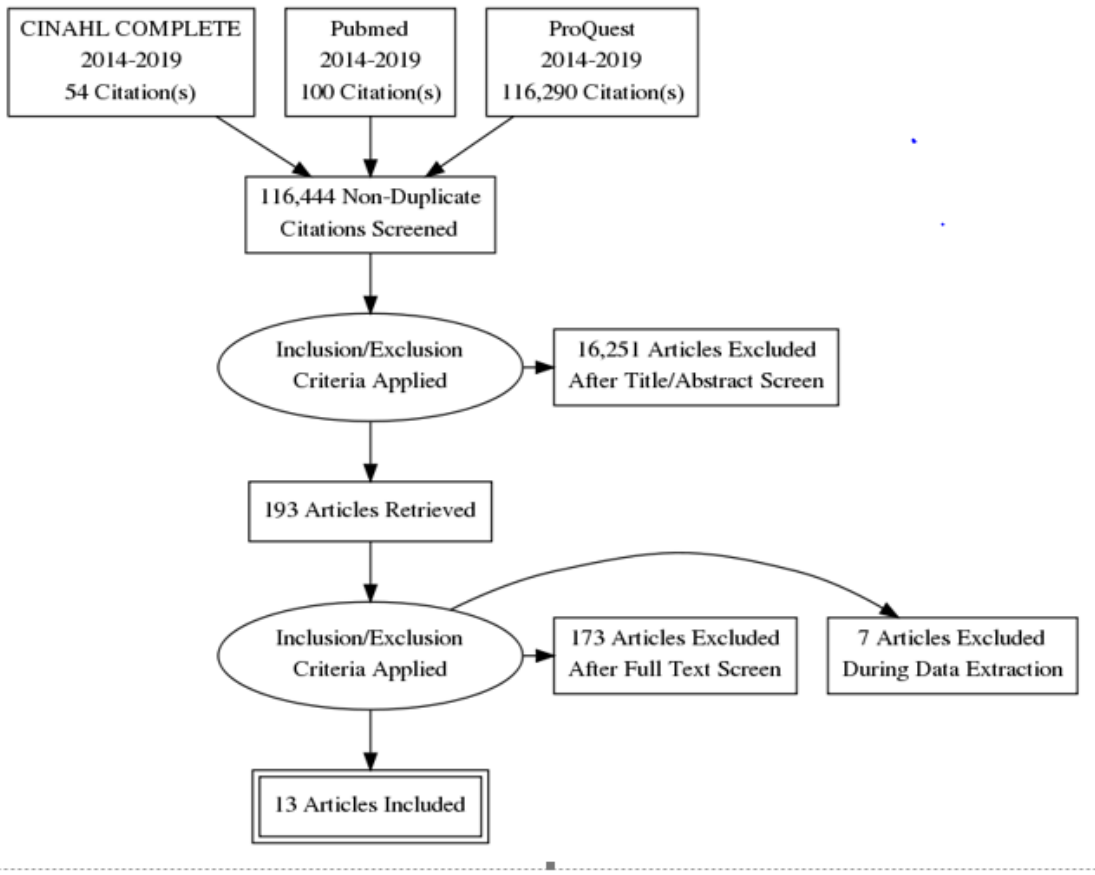

Figure 1. Flow chart of PRISMA model for literature review search.

The 13 articles retrieved from the literature review were evaluated using the Strength of Recommendation Taxonomy (SORT) to determine the quality of individual study and the strength of the recommendation based on the body of evidence. The A-level recommendation was reserved for articles that had good-quality patient-oriented evidence, while B-level was used for articles that were irregular or of limited-quality, patient-oriented evidence (Ebell et al., 2004). 
Finally, the C-level was reserved for articles based on consensus, standard practice, and opinion (Ebell et al., 2004). The 13 articles included in the DNP project were all rated A-level. Following the in-depth evaluation of the literature and using the algorithm recommended by the Strength of Recommendation Taxonomy SORT (Ebell et al., 2004), eight articles with Level 1 evidence were included. There were two articles selected for Level 2 due to limited quality evidence. Finally, there were three articles rated in Level 3 due to consensus guidelines and usual methods.

\section{Themes from the Literature}

Synthesizing the literature review involved the process of combining ideas or emerging elements needed in the project or to answer the PICOT question (Fries-Gaither, 2010). Literature reviews were organized sequentially, by topic, theme, method, results, theory, or argument to generate categories that were meaningful and relevant to the research question (Fries-Gaither, 2010).

The first step of the literature review was reading over study reports that had used checklist for patient safety. Seven studies employed checklists to provide accurate and complete data, prevent errors, and improve performance (Gillespie, Withers, Lavin, Gardiner, \& Marshall, 2016; Huber et.al., 2017; Kozusko, Elkwood, Gaynor, \& Chagares, 2016; Lea et al., 2016; Ruggiero, Smith, Copeland, \& Boxer, 2015; Shear et al., 2018; Westmore, 2016). Checklists were used in a variety of settings, such as operating rooms, intensive care, outpatient, and inpatient areas. The utilization of a checklist, regardless of its purpose and intent, exhibited a Level 1A: evidence of good to high-quality SORT criteria. See Appendix C for a summary of primary research evidence, and Appendix D for a summary of systematic reviews.

The second theme exhibited in the review was implementing "timeout" in medication reconciliation. "Timeout" intervention yielded Level 1-3, quality grade A using SORT criteria. 
The timeout on medication reconciliation was modeled after the operative timeout process. In four articles, the application of "timeout" was used as a as part of the intervention in medication reconciliation and produced positive outcomes (Lai, Anderson, Weinberg, \& Rosenblatt, 2015; Shear et al., 2018; Singh, \& Zughaib, 2019; Tainter et al., 2018). Refer to Appendices C and D for more information.

The third theme identified was that the collaborative effort between the pharmacists and the healthcare team significantly reduced medication variances. The results of studies examining collaborative interventions among staff displayed good quality evidence 1-2, A Level from SORT criteria (Hazelton et al., 2015; Weingessel et al., 2017). See Appendices C and D for more results.

\section{Practice Recommendations}

After conducting the review of literature directed by the PICOT question, and grading the evidence of the results, the synthesized recommendation for reducing medication errors was the application of the MRTP. The scientific evidence of the reviewed articles supported the use of a checklist. The utilization of a checklist in the medication reconciliation, in addition to a "timeout" process, synergized the reduction of medication errors. The intervention was a good fit for the particular hospital setting, particularly given limited electronic health record (EHR) availability.

The Institute of Healthcare Improvement (IHI) recommended that accuracy should be present in every step in the medication reconciliation process (IHI, 2019). A structured approach to patient care can improved compliance through the use of checklists. The MRTP was modified from a surgical checklist used in operations for the prevention of medical errors. (Tainter et al., 2018). At admission, the patient underwent a timeout process during which a nurse completed a 
checklist to identify discrepancies such as medication omission, duplication, change in frequency, change in doses, and adjustment. A second nurse used the checklist for accuracy before transmitting information to the pharmacist. As suggested by the Institute of Healthcare Improvement (IHI, 2019), the checklist contained the data needed to collect and maintain an updated medication list. It was used to verify, clarify, reconcile, and transmit the correct medication information. See Appendix G for the MRTP checklist.

\section{Project Setting}

The setting of the project was a small, 50-bed, long-term acute care hospital in South Texas. The facility was a specialty care institution for patients who needed a bridge for a continuum of care and required immediate and long-term care treatment (Cornerstone Healthcare Group, 2019). The chosen facility, which carried the mission of providing exceptional patient care and assistance to inpatient adults in intensive care, telemetry, and medical-surgical units (Cornerstone Healthcare Group, 2019). To achieve this mission, the stakeholders, primarily the hospital leadership, verbalized a need to reduce the incidence of medication errors. The director of pharmacy and the director of quality stated the importance of conducting a targeted evidencebased project to increase compliance in medication reconciliation and to decrease medication errors. An organizational assessment was thus completed using a Strength Weakness Opportunity Threat (SWOT) analysis. Results can be found in Appendix B.

\section{Project Overview}

The vision of the proposed project was to reduce the medication error incidence by $10 \%$ of the current rate, and the mission was to implement MRTP among nurses to do so. The congruence of the project's vision and mission with those of the hospital supported the implementation. The short-term goal of the project was to see collaboration among the 
stakeholders in the implementation of the MRTP intervention. The long-term goals of the project were for it to be sustained for three years or more in the chosen hospital, and to achieve a $50 \%$ to $75 \%$ reduction of medication errors over a three-year period.

\section{Project Description}

Lewin's Change Management Theory was the change model used for the project. The model explained human behavioral experience when facing any pattern of change and resistance (Sutherland, 2013). Lewin's theory was appropriate for the facility due to the new intervention of the timeout process in medication reconciliation for organizational change. Lewin's model featured three distinct stages: unfreezing, moving, and refreezing (Bosak, 2003). The objective of the model was to identify factors that hinder change from happening. The initial stage of unfreezing required identifying the key players that affected by the change of implementation of the MRTP, such as the frontline nurses, administration, and pharmacists. In this stage, the team had to opened communication to identify the factors that would have made the project succeed or fail. The second stage was the moving stage, during which the actual change process occurred. The timeline, workflow and education training were essential in this stage to finish the project (Spetz, Burgess, \& Phibbs, 2012). Refreezing was the last stage of the theory and implementation of the MRTP checklist. This was when the stability and sustainability of the project were evaluated to determine any possible problems that occurred during the implementation stage.

The MRTP was implemented across all of the admissions in the facility. The MRTP patterned in the surgical best practice used a "Timeout" and checklist to review essential safety elements before surgery. In this project, two nurses checked the medication reconciliation before faxing required medication to the pharmacist with a completed timeout checklist. In the previous 
practice, two professionals (the pharmacist and a nurse) had checked the medication

reconciliation. The implementation of MRTP included review by two nurses simultaneously and then by the pharmacist. The collaborative effort of the pharmacist, nurses, and provider resulted in the reduction of medication errors in the facility.

The utilization of the impact/risk formula in assessing risk factors for the success of the Medication Reconciliation Timeout Process project exposed two risks: inadequate education, and leadership disengagement. The lack of education and training reduced the impact of the project, and the probability of failure was elevated because no full-time educator was currently assigned to the hospital. The training/education was a shared responsibility with the chief nurse officer (CNO). Creating Medication Reconciliation Champions alleviated the CNO's burden. The medication reconciliation champions assisted in the educational MRTP training, which was done consistently during new nurse orientation, yearly competency, and on every shift if needed. The second risk identified was leadership disengagement. An interview with the frontline staff and other leaders showed that previous programs had not been successful due to minimal involvement of the facility's leaders. To combat this issue, weekly huddles were conducted within the leadership team to discuss medication errors. The huddles were led by the pharmacist or the medication reconciliation leadership champion.

The approval letter for the project was submitted and received from the University of St. Augustine for Health Sciences (USAHS) Evidence-Based Practice Review Council (see Appendix J). This approval letter was followed by the submission to the facility's leadership team (see Appendix K for facility approval letter). The next step was the one-week education training for the nurses on the MRTP. The total duration of the project, from implementation to completion was four weeks. See Appendix E for a detailed project timeline. 
The project budget was small. The main costs of the project, $\$ 350$, were printing educational materials, handouts, and flyers to promote the new MRTP initiative. A minimal budget of \$200 was allocated to the Kaizen event. The total project costs were approximately \$550. See Appendix F for more detailed budgetary breakdown.

\section{Project Evaluation}

The evaluation of the project was completed by determining the medication error rate at pre and post-project intervention through chart review audits of 20 patients. The data came from components of proper medication reconciliation, such as the documentation of allergies, omitted medications, error in transcription, or any elements considered as medication errors. The goal was to review 20 charts for four weeks before the implementation of MRTP to determine the current medication error before the intervention. After four weeks of implementation of the MRTP, designated Champions conducted a 20-chart audit to determine the improvement of medication errors.

Another outcome measure included was the compliance of the nurses to the new intervention, with a goal of $80 \%$ and above for the adherence rate. The purpose of the project was to reduce medication errors by implementing MRTP. The population, all of whom were nurses played a critical role in the reduction of medication errors. It was essential to address the nurses' years of experience and their education, as the literature review findings suggested these factors had a significant association with medication errors. The article of Sears, O'Brien-Pallas, Stevens, \& Murphy (2016) cited that a higher level of nursing experience-reported in less severe medication errors. The variables included in the project were years of experience, education background, and job title. See Appendix $\mathrm{H}$ for the data analysis. 


\section{Project Evaluation Results}

A collaborative effort with statisticians assisted the data analysis and interpretation. The raw data was recorded and analyzed, utilizing the SPSS software, version 23. Descriptive statistics were included in the analysis of the data and evaluated to answer if any statistical relationship existed between medication error rate and admission medication reconciliation preand post-intervention. Statistical analyses included calculation of frequencies, means, standard deviation, and change percentage. See Appendix H for the complete list of variables presented for the project.

\section{Participants' Demographic Data}

The project's participants were 20 house supervisors and 20 primary nurses. The participants were directly involved with medication reconciliation during admission at the hospital. Participants' demographic information was obtained from the CNO, which included gender, job title, years of experience, and educational background. The aggregated results for these demographics are included in Figures 2 through 5.

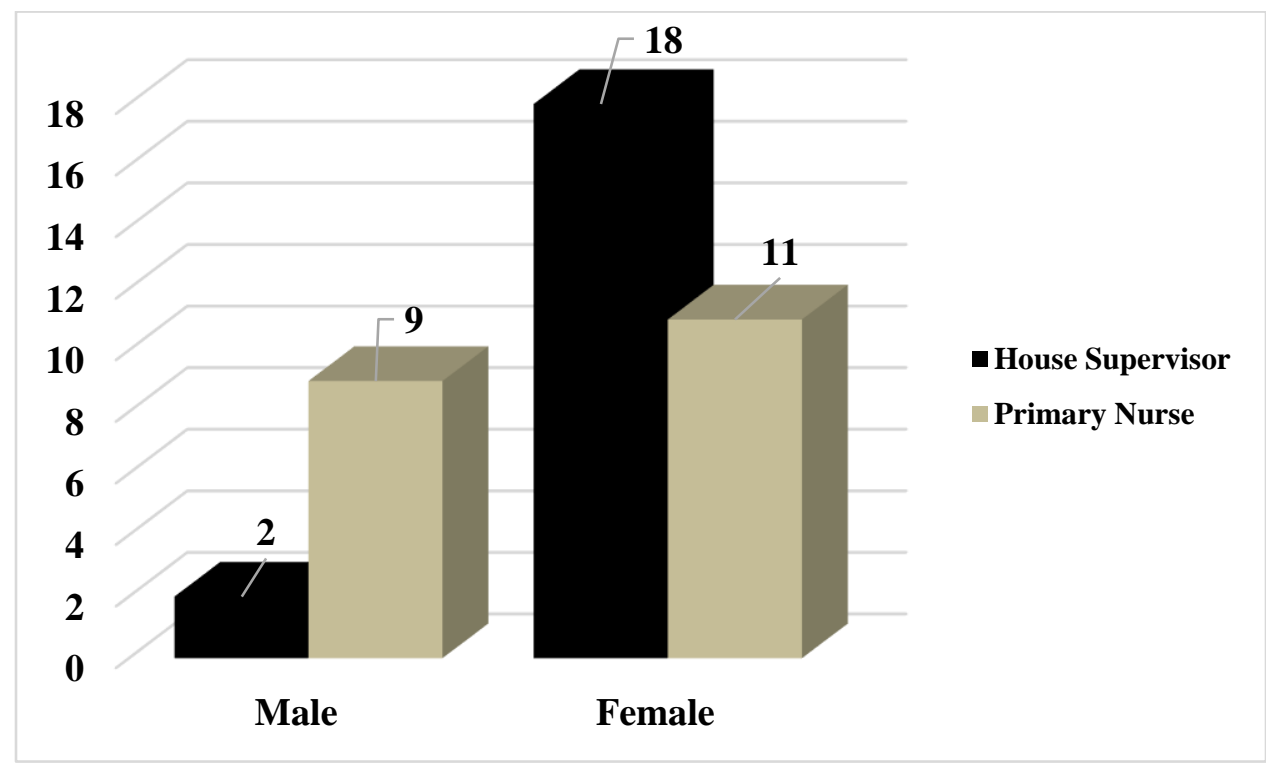

Figure 2. Gender of participants. 
The ratio of female to male participants was 29 to 11 , respectively: $10 \%$ were male, and $n=18$ or $90 \%$ were female. The gender of the house supervisor was attributed as $n=2$. Of the primary nurses, $n=9$ or $45 \%$ were male, and $n=11$ or $55 \%$ were female.

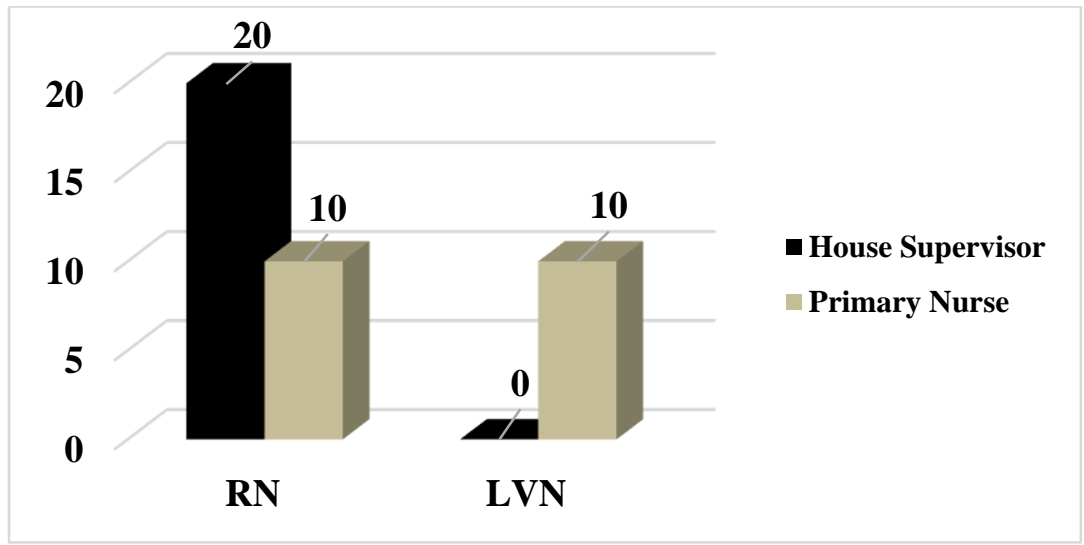

Figure 3. Job title of participants.

The ratio of License Vocational Nurses (LVN) to Registered Nurses (RN) participants was 10 to 30, respectively. The program included both RNs and LVNs. All of the house supervisors ( $n=20$, or $100 \%$ ) were RNs. The primary nurses were divided into $n=10$ or $50 \%$, who were RNs, and the other $n=10$ or $50 \%$, who were LVNs.

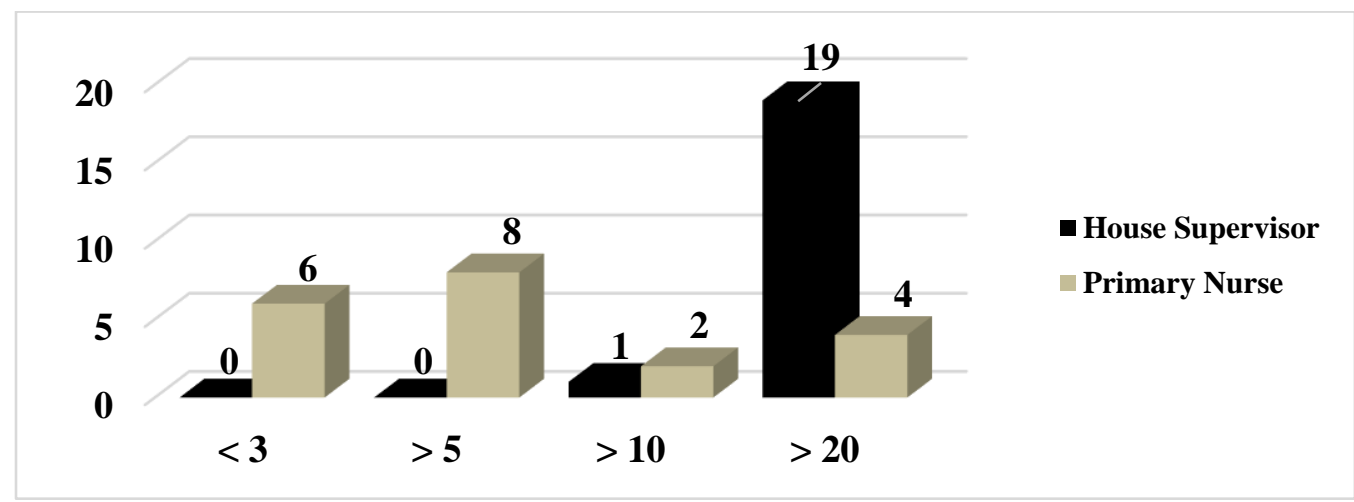

Figure 4. Years of experience of participants.

The figure shows that $n=1$ or $5 \%$ of house supervisors had work experience greater than 10 years, while $n=19$ or $95 \%$ had greater than 20 years. Six or $30 \%$ of primary nurses had 
experience of less than three years, $n=8$ or $40 \%$ were greater than five years, $n=2$ or $10 \%$ had greater than 10 years, and $n=4$ or $20 \%$ had greater than 20 years of experience.

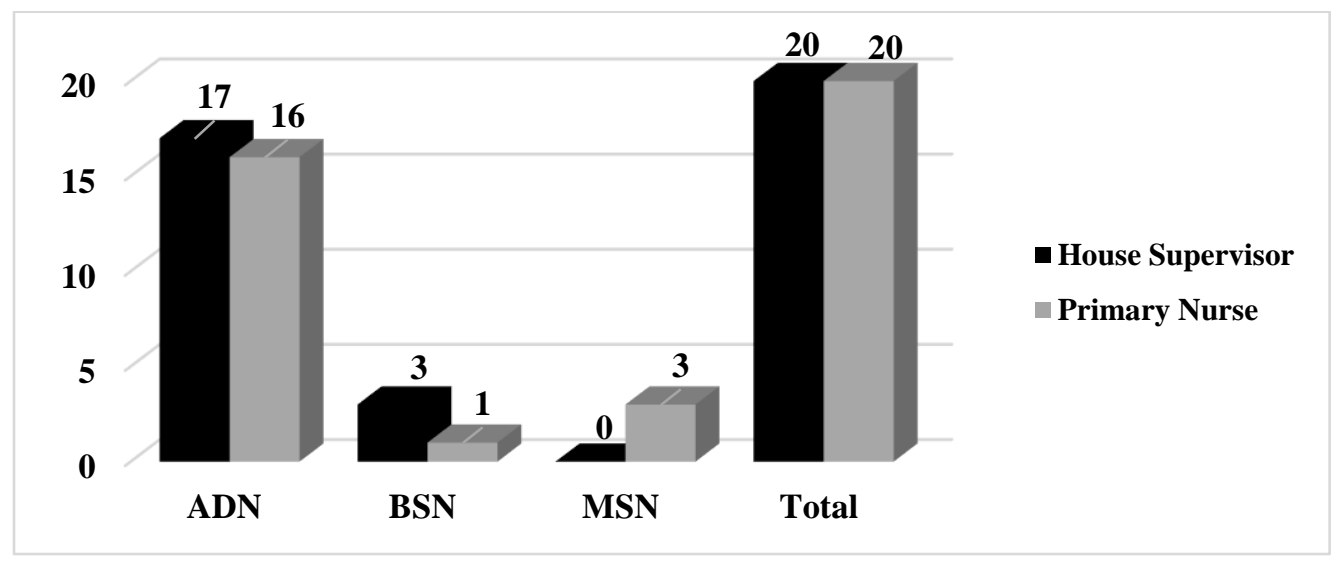

Figure 5. Educational attainment of participants.

This figure shows that $n=17$ or $85 \%$ of the house supervisors reached the ADN level of educational attainment, and $n=3$ or $15 \%$ attained their BSN. Sixteen or $80 \%$ of primary nurses reached an educational attainment of $\mathrm{ADN}$ while, $n=1$ or $5 \%$ were holders of a BSN, and $n=3$ or $15 \%$ had MSN degrees.

\section{Medication Error Rate}

The medication error rate was obtained by conducting chart reviews of 20 patients before and after implementation of the MRTP. The medication error rate was measured by dividing the total number of medication errors by the total number of medications ordered. Refer to Table 1 for the computation of medication error rates. The baseline medication error rate was 46 , or 14.88\%. A month after the implementation of MRTP, the medication error rate had dropped to 10 , or $3.88 \%$. See Table 1 for the medication rate data.

$\underline{\text { Table } 1}$ Medication Error Rate

\begin{tabular}{c|c|c|c}
$\begin{array}{c}\text { Medication } \\
\text { Errors }\end{array}$ & $\begin{array}{c}\text { Total Number of } \\
\text { Medications }\end{array}$ & $\begin{array}{c}\text { Raw } \\
\text { Score }\end{array}$ & $\begin{array}{c}\% \text { Medication } \\
\text { Error Rate }\end{array}$ \\
\hline
\end{tabular}




\begin{tabular}{l|c|c|c|c}
\hline $\begin{array}{l}\text { Pre } \\
\text { MRTP }\end{array}$ & 46 & 309 & 0.1488 & 14.88 \\
\hline $\begin{array}{l}\text { Post } \\
\text { MRTP }\end{array}$ & 10 & 265 & 0.0377 & 3.77 \\
\hline
\end{tabular}

\section{Statistical Analysis}

The performance improvement project utilized the SPSS for data analysis of measurement and interpretation. To determine the project's statistical significance, an unpaired ttest was completed to compare the medication error rates before and after the implementation of MRTP. The $p$ value $=$ or $<0.05$ was the determinant for the evidence-based project's statistical significance. See Table 2 for the pre -and post -Medication Reconciliation unpaired t-test statistics.

$\underline{\text { Table } 2}$

$\underline{\text { Pre- and Post-Medication Reconciliation Unpaired T-Test Statistics }}$

\begin{tabular}{|c|c|c|c|c|c|c|}
\hline Medication & $\mathbf{N}$ & Mean & SD & df & t-value & p-value \\
\hline Pre- & 20 & 2.30 & 1.75 & & & \\
\hline $\begin{array}{l}\text { Reconciliation } \\
\text { Post - } \\
\text { Reconciliation }\end{array}$ & 20 & 0.50 & 1.15 & 38 & 3.847 & 0.000 \\
\hline
\end{tabular}

As seen in in Table 2, there was statistically significant difference between the score of pre- $(\mathrm{M}=2.30, \mathrm{SD}=1.75)$ and post $(\mathrm{M}=0.50, \mathrm{SD}=1.15)$ conditions. The t-value was 3.847, which was significant at alpha $=.05$, resulting in a statistically significant difference between the participants' results of pre- and post-MRTP. 


\section{Discussion and Implications}

In this project, the utilization of MRTP was clinically significant because it decreased medication errors. When two nurses performed timeout and utilized a checklist on medication reconciliation, they promoted patient safety and reduced medication errors. Accurate and complete information was present when initiating medication reconciliation. This resulted in the reduction of medication discrepancies.

The major outcome of the findings of the project was the reduction of medication errors due to MRTP intervention. Pre-intervention, 20 were reviewed), and 17 (or $85 \%$ ) charts had at least one medication error. Therefore, only 3 (or 15\%) were correct. In one month, the implementation of the MRTP checklist dramatically reduced the medication error rate from $14.88 \%$ to $3.88 \%$. See Table 1 for the complete data.

Another outcome measure identified in the project was the nurse compliance with MRTP checklist. It was expected that all admission nurses would utilize the MRTP checklist. While medication error rates improved post-intervention, the nurse compliance rate did not surpass the initial goal of more than $80 \%$ compliance. There were 44 admissions for June, and only 23 MRTP checklists submitted to the CNO. Therefore, the nurse compliance rate to the MRTP was only $52 \%$. Refer to Table 3 for nurse compliance rate data. One significant reason for the low nurse compliance rate was the accessibility of the checklist. For the first three weeks of implementation checklist were placed in the house supervisor's folder in the huddle room. After the MRTP Team's evaluation of the problem, the solution was to place the checklist in the admission packet for easy accessibility. Over the last week, there was an increased compliance of nurses utilizing the MRTP checklist.

\section{$\underline{\text { Table } 3}$}


Nurse Compliance Rate

\begin{tabular}{ccc}
\hline Nurse Compliance to MRTP & Frequency & Percentage \\
& $\mathrm{f}$ & $\%$ \\
\hline Nurse Compliance to MRTP checklist & 23 & 52 \\
Nurse Non-Compliance to MRTP checklist & 21 & 48 \\
Total & $\mathbf{4 4}$ & $\mathbf{1 0 0}$ \\
\hline
\end{tabular}

The CNO conducted MRTP training for all nurses for 1 week. The house supervisors, also serving as the MRTP champions, assisted in educating all the facility's nurses using the prepared PowerPoint presentation. See Appendix I for detailed contents of the training. A total of 40 nurses participated in training: 20 house supervisors and 20 primary nurses (see Figure 6).

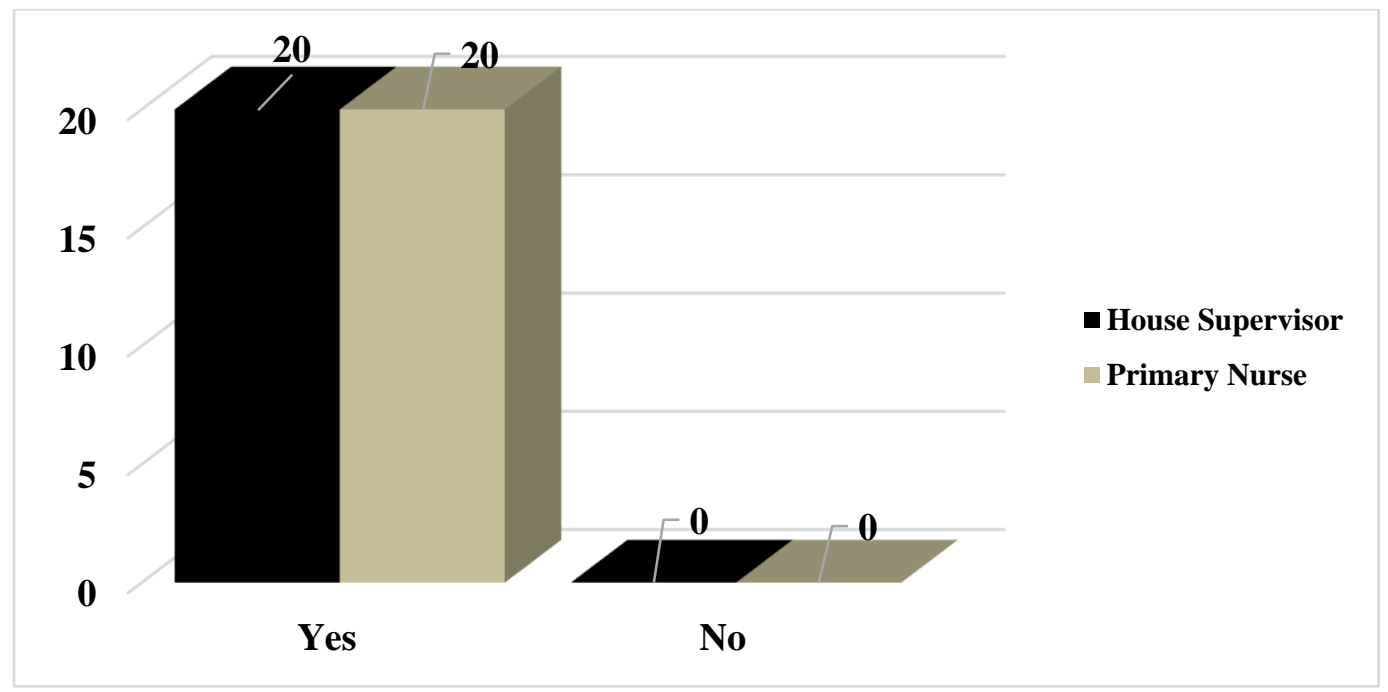

Figure 6. MRTP training.

A few nurses initially resisted the practice change, but with constant education and the CNO's direct involvement, their opposition dissipated. Another factor that helped the nurses transition from the resistance stage into the participative stage was being presented with facts about the pre-intervention medication error rate. Once they knew that there was a practice gap in medication reconciliation, facility's nurses were receptive to improving the current process. 
Medication reconciliation was a collaborative effort of the health care team. An accurate medication reconciliation decreased medication discrepancies and medication errors. The MRTP intervention's success was possible when two nurses are simultaneously checked for accuracy, transcription errors, and completeness of medication reconciliation by using a checklist. Incorporating "timeout" during the medication reconciliation process allowed the two nurses to pause immediately to confirm the correct medication information. The utilization of the best practice of MRTP resulted in providing safer and improved quality care in clinical practice.

\section{Dissemination}

Matus, Wenke, and Mickan (2019) cited the importance of disseminating the result of a project or toolkit by the leadership team and other interprofessional staff (2019). The collaborative involvement of the whole team increased project buy-in and facilitated clarity of communication. The distribution of evidence-based project should encourage extensive implementation of changes in practice, particularly with patient safety (Berman, Raval, \& Goldin, 2018).

The Agency for Healthcare Research and Quality (AHRQ, 2018) suggested six main elements in the dissemination plan:

- Project findings- What is going to propagate?

- End-user- Who will implement the practice?

- Disseminate partner- What network/affiliation will be used to reach the end-user?

- Communication- What tool will be used to convey the message?

- Evaluation- How did the participants receive the project? What is the feedback?

- Designate work plan- What are the action items, schedule, and the person responsible? (AHRQ, 2018). 


\section{Internal Dissemination}

The project's results were shared first with hospital leaders. This process was initiated by the pharmacy director, $\mathrm{CNO}$, and quality director during weekly leadership meetings. Furthermore, the CNO will continue to share the project's outcomes with the nursing service through the monthly nursing meeting. Further, the information will be provided to all staff this fall during a competency fair. The quality director will also discuss the success of the project with the Quality Committee and the Medical Executive Board quarterly meetings.

\section{External Dissemination}

The facility will share the outcomes of the evidence-based system-change project among the affiliated network of long-term, acute-care hospitals that operate in different localities and states nationwide. A further aspect of external dissemination will include presenting during Philippine Nursing Association (PNA) Conference. The PNA holds two major conferences every year, which are attended by nursing delegates from different regions and localities throughout the United States.

Also, this paper will be disseminated in full text to SOAR@USA to fulfill DNP program requirements.SOAR@USA is an institutional repository that will enhance the availability and discoverability of the DNP scholarly project. Finally, the project will be presented to the Virginia Henderson Global Nursing e-Repository to promote worldwide dissemination of the DNP project information.

\section{Conclusion}

The evidence-based project focused on developing an evidence-based practice intervention to address medication safety problems that arose from inaccurate medication reconciliation. The project evaluated the reduction of medication errors after the initiation of the 
MRTP in the hospital. The implementation of the MRTP decreased medication errors, thus improving patient outcomes. The project started with an organizational needs assessment and SWOT analysis. The institutional problem was the increasing rate of medication errors from poor medication reconciliation. The medication error rate had risen to115 occurrences in 2019 .

Lewin's Change Management Theory was the preferred change model for the project because it supported the utilization of impact/risk assessment. The success of the project was measured by nursing team's use of timeout and the checklist in medication reconciliation. Consistent educational training and purposeful audits propelled the success of the project. The support of multidisciplinary team made up of nurses, providers, patients, and leadership was also the key of the project's accomplishments.

The primary results of the project were the reduction in the medication error rate and incidence, which improved patient healthcare outcomes. The outcome of the project was a significant reduction in the medication error rate, from $14.88 \%$ to $3.77 \%$, after implementation of the evidence-based intervention. Implementation of MRTP resulted in an $11.11 \%$ decreased in medication errors within four weeks in a long-term acute care facility. 


\section{References}

Aldhafeeri, N. A., \& Alamatrouk, R. (2019). Shaping the future of nursing practice by reducing medication error. Pennsylvania Nurse, 74(1), 14-19.

Agency for Healthcare Research and Quality. (2018). Dissemination. Retrieved from https://www.ahrq.gov/research/findings/final-reports/crcscreeningrpt/crcscreen5.html

Bates, D W., \& Slight, S. (2014) Medication errors: What is the impact? Mayo Clinic Proceedings, 89(8),1027-1029. doi:10.1016/j.mayocp.2014.06.014

Berman, L., Raval, M. V., \& Goldin, A. (2018). Process improvement strategies: Designing and implementing quality improvement research. Seminars in Pediatric Surgery, 27(6), 379385. doi:10.1053/j.sempedsurg.2018.10.006

Bozak, M. G. (2003). Using Lewin's force field analysis in implementing a nursing information system. CIN: Computers, Informatics, Nursing, 21(2), 80-85.doi:10.1097/00024665200303000-00008

Chen, Y., Wu, X., Huang, Z., Lin, W., Li, Y., Yang, J., \& Li, J. (2019). Evaluation of a medication error monitoring system to reduce the incidence of medication errors in a clinical setting. Research in Social and Administrative Pharmacy, 15(7), 883-888. doi: 10.1016/j.sapharm.2019.02.006

Cornerstone Healthcare Group. (2019). Solara specialty hospitals McAllen-LTACH. Retrieved from http://chghospitals.com/location/solara-specialty-hospitals-mcallen/.

Dellabarca, T. (2019). Organizational culture and its impact on medication safety. Dissector, 47(1), 27-29.

Ebell, M. H., Siwek, J., Weiss, B. D., Woolf, S. H., Susman, J., Ewigman, B., \& Bowman, M. (2004). Strength of Recommendation Taxonomy (SORT): A patient-centered approach to 
grading evidence in the medical literature. The Journal of the American Board of Family Medicine, 17(1), 59-67. doi:10.3122/jabfm.17.1.59

Fries, J. (2010). Summarizing and synthesis: What's the difference? Retrieved from https://beyondpenguins.ehe.osu.edu/issue/climate-change-and-the-polarregions/summarizing-and-synthesizing-whats-the-difference

Frydenberg, K., \& Brekke, M. (2012). Poor communication on patients' medication across health care levels leads to potentially harmful medication errors. Scandinavian Journal of Primary Health Care, 30(4), 234-240. doi:10.3109/02813432.2012.712021

Gao, M. C., Martin, P. B., Motal, J., Gingras, L. F., Chai, C., Maikoff, M. E., ,Ä Eiss, B. M. (2018). A multidisciplinary discharge timeout checklist improves patient education and captures discharge process errors. Quality Management in Health Care, 27(2), 63-68D doi:10.1097/QMH.0000000000000168

Gillespie, B. M., Withers, T. K., Lavin, J., Gardiner, T., \& Marshall, A. P. (2016). Factors that drive team participation in surgical safety checks: A prospective study. Patient Safety in Surgery, 10.

Hazelton, J.P, Ofe, E.C, Colacion, A.M, Hunter, K, Caprano-Wehrle, L.M, Lachant, M.T...Seamon, M.J. (2015). The impact of a multidisciplinary safety checklist on adverse procedural events bedside bronchoscopy-guided percutaneous tracheostomy. Journal of Trauma Acute Care Surgery, 79(1): 111-116. doi:10.1097/TA.0000000000000700

Huber, T., Brinkmann, F., Lim, S., Schröder, C., Stekhoven, D., Marti, W., ... Egger, R. R. (2017). Implementation of an IT-guided checklist to improve the quality of medication 
history records at hospital admission. International Journal of Clinical Pharmacy, 39(6), 1312-1319. doi:10.11096-017-0545-0

Hughes, R. \& Blegen, M. (2008). Medication administration safety. Rockville (MD): Agency for Healthcare Research and Quality (US). Chapter 37.

Institute for Healthcare Improvement. (2019). Accuracy at every step: The challenge of medication reconciliation. Retrieved from http://www.ihi.org/resources/Pages/ImprovementStories/AccuracyatEveryStep.aspx

Kaminski, J. (2011). Diffusion of Innovation Theory. Canadian Journal of Nursing Informatics.6(2) 1-2. Retrieved from http://cjni.net/journal/?p=1444

Kozusko, S. D., Elkwood, L., Gaynor, D., \& Chagares, S. A. (2016). An innovative approach to the surgical time out: A patient-focused model: The official voice of perioperative nursing the official voice of perioperative nursing. AORN Journal, 103(6), 617-622.

doi:10.1016/j.aorn.2016.04.00

Lai, Y. H., Anderson, M. R., Weinberg, A. D., \& Rosenblatt, M. A. (2015). Positive perceptions on safety and satisfaction during a patient-centered timeout before peripheral nerve blockade. Journal of Clinical Anesthesia, 27(3), 214-220. doi:

10.1016/j.jclinane.2014.10.009

LaMorte, W. (2019). Behavioral Change Model. Diffusion of Innovation Theory. Retrieved from http://sphweb.bumc.bu.edu/otlt/MPHModules/SB/BehavioralChangeTheories/BehavioralChangeTheories4.html 
Lea, M., Barstad, I., Mathiesen, L., Mowe, M., \& Molden, E. (2016). Effect of teaching and checklist implementation on accuracy of medication history recording at hospital admission. International Journal of Clinical Pharmacy, 38(1), 20-24.

doi:10.1007/s11096-015-0218-9

Matus, J., Wenke, R., \& Mickan, S. (2019). A practical toolkit of strategies for building research capacity in allied health. Asia Pacific Journal of Health Management, 14(2), 5-18. doi:10.24083/apjhm. v14i2.261

Ruggiero, J., Smith, J., Copeland, J., \& Boxer, B. (2015). Discharge time out: An innovative nurse-driven protocol for medication reconciliation. Medical Surgical Nursing, 24(3), 165-172.

Sears, K., O’Brien-Pallas, L., Stevens, B., \& Murphy, G. T. (2016). The relationship between nursing experience and education and the occurrence of reported pediatric medication administration errors. Journal of Pediatric Nursing, 31(4), e283-e290. doi: 10.1016/j.pedn.2016.01.003

Shear, T., Deshur, M., Avram, M. J., Greenberg, S. B., Murphy, G. S., Ujiki, M., ,Ä Wijas, B. (2018). Procedural timeout compliance is improved with real-time clinical decision support. Journal of Patient Safety, 14(3), 148-152. doi:10.1097/PTS.0000000000000185

Singh, R., \& Zughaib, M. (2019). Timeout for contrast: Using physician behavior modification to reduce contrast in the catheterization laboratory. Cardiology Research \& Practice, 16. doi:10.1155/2019/9238124

Southard, K. (2005). Barcoding medication administration: Preparing the culture for change. Nurse Leader, 3(3), 53-55. doi:10.1016/j.mnl.2005.02.009 
Tainter, C. R., Nguyen, A. P., Pollock, K. A., O'Brien, E., O., Lee, J., Schmidt, U., . . Meier, A. (2018). The impact of a daily "medication time out" in the intensive care unit. Journal of Critical Care, 43, 366-369. doi:10.1016/j.jcrc.2017.09.018

Tariq, R.A., \& Scherbak, Y. (2019). Medication errors. Treasure Island, FL: Stat Pearls Publishing. https://www.ncbi.nlm.nihgov/books/NBK519065/.

The Joint Commission. (2015). National patient safety goals. Retrieved from http://www.jointcommission.org/assets/1/6/2015_npsg_hap.pdf

Weingessel, B., Haas, M., Vécsei, C., \& Vécsei-Marlovits, P. V. (2017). Clinical risk management - a 3-year experience of team timeout in 18081 ophthalmic patients. Acta Ophthalmologica, 95(2), e89-e94. doi:10.1111/aos.13155

Wetmore, D., Goldberg, A., Gandhi, N., Spivack, J., McCormick, P., \& DeMaria, S. (2016). An embedded checklist in the anesthesia information management system improves preanesthetic induction setup: A randomized controlled trial in a simulation setting. $B M J$ Quality \& Safety, 25(10), 739. doi:10.1136/bmjqs-2015-004707

World Health Organization. (2017). Global campaign: Medication without harm. Retrieved from http://www.who.int/patientsafety/medication-safety/Campaign/en/ 


\section{Appendix A}

\section{PRISMA Flow Diagram Generator}

Medication Reconciliation Timeout Process

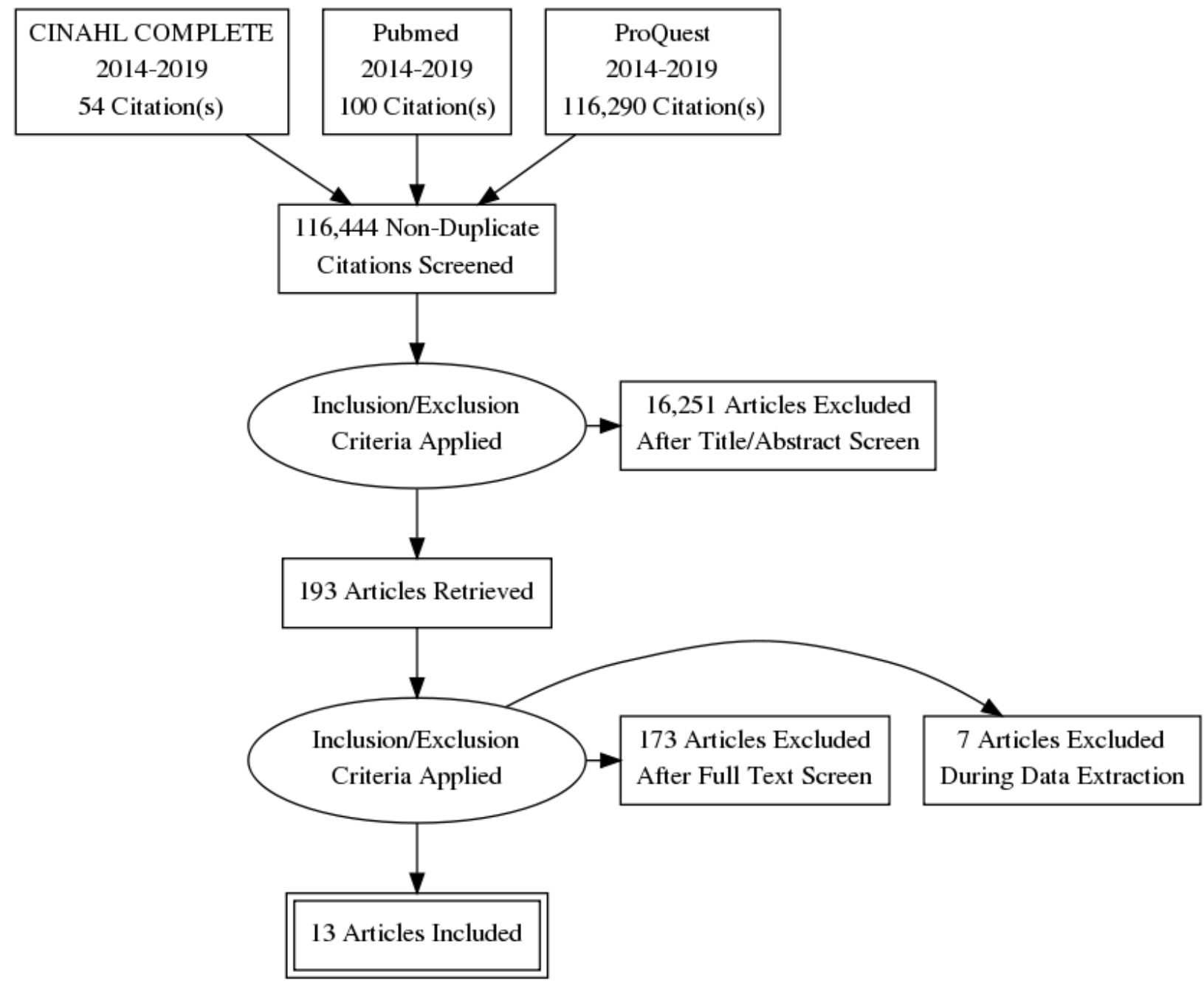

Figure 1 Flow chart of Prisma Model Medication Reconciliation Timeout Process 


\section{Appendix B}

SWOT Analysis

\begin{tabular}{|c|c|}
\hline Internal Forces (Project) & External Forces (Organizational /Environment) \\
\hline Strengths & Opportunities \\
\hline $\begin{array}{l}\text { *Evidence-Based Intervention } \\
\text { *Short Time-Frame: Attainable Goal to Decrease } \\
\text { Medication Error Incidence } \\
\text { *Full Administrative Support }\end{array}$ & $\begin{array}{l}\text { *Spot Education Champion } \\
\text { *Stream line and Upgrade Medication } \\
\text { Reconciliation Process }\end{array}$ \\
\hline Weaknesses & Threats \\
\hline $\begin{array}{l}\text { *Small Hospital: 50-Bed Capacity } \\
\text { *No CNO: Only Acting CNO } \\
\text { *No Educator Provided (FTE) Inconsistent Education } \\
\text { *Attitude of Resistance to Change by Nurses }\end{array}$ & $\begin{array}{l}\text { *Solara: Partial EHR } \\
\text { *Many Newly Hired Nurses with Less Than One-Year of } \\
\text { Experience: Need Education }\end{array}$ \\
\hline
\end{tabular}


Appendix C

Summary of Primary Research Evidence

\begin{tabular}{|c|c|c|c|c|c|c|}
\hline Citation & $\begin{array}{l}\text { Design, } \\
\text { Level } \\
\text { Quality } \\
\text { Grade }\end{array}$ & $\begin{array}{l}\text { Sample } \\
\text { Sample } \\
\text { size }\end{array}$ & $\begin{array}{l}\text { Intervention } \\
\text { Comparison } \\
\text { (Definitions } \\
\text { should } \\
\text { include any } \\
\text { specific } \\
\text { research tools } \\
\text { used along } \\
\text { with } \\
\text { reliability \& } \\
\text { validity) }\end{array}$ & $\begin{array}{l}\text { Theoretical } \\
\text { Foundation }\end{array}$ & $\begin{array}{l}\text { Outcome } \\
\text { Definition }\end{array}$ & $\begin{array}{c}\text { Usefulness } \\
\text { Results } \\
\text { Key } \\
\text { Findings }\end{array}$ \\
\hline $\begin{array}{l}\text { Gao, M. C., Martin, P. B., Motal, J., Gingras, L. F., Chai, } \\
\text { C., Maikoff, M. E., , Ä Eiss, B. M. (2018). A } \\
\text { multidisciplinary discharge timeout checklist } \\
\text { improves patient education and captures } \\
\text { discharge process errors. Quality Management in } \\
\text { Health Care, 27(2), 63-68. } \\
\text { doi:10.1097/QMH.0000000000000168 }\end{array}$ & $\begin{array}{l}\text { Quality } \\
\text { improvem } \\
\text { ent design } \\
\text { SORT } \\
\text { Level 1A }\end{array}$ & $\mathrm{N}-429$ & $\begin{array}{l}\text { Utilization of } \\
\text { timeout and } \\
\text { checklist } \\
\text { prior to } \\
\text { discharge. }\end{array}$ & $\begin{array}{l}\text { Model of } \\
\text { Improvement } \\
\text { framework }\end{array}$ & $\begin{array}{l}\text { To create and } \\
\text { implement a } \\
\text { discharge timeo } \\
\text { ut checklist and } \\
\text { to evaluate its } \\
\text { impacts on } \\
\text { patients' } \\
\text { understanding } \\
\text { as well as the } \\
\text { possible effects } \\
\text { on preventable } \\
\text { medical errors } \\
\text { in terms of } \\
\text { hospital } \\
\text { discharges to } \\
\text { home. }\end{array}$ & $\begin{array}{l}\text { Multidiscipli } \\
\text { nary timeout } \\
\text { process } \\
\text { significantly } \\
\text { reduces } \\
\text { errors, } \\
\text { enhances } \\
\text { patient } \\
\text { safety and } \\
\text { preventable } \\
\text { adverse } \\
\text { errors. }\end{array}$ \\
\hline $\begin{array}{l}\text { Gillespie, B. M., Withers, T. K., Lavin, J., Gardiner, T., } \\
\text { \& Marshall, A. P. (2016). Factors that drive team } \\
\text { participation in surgical safety checks: A } \\
\text { prospective study. Patient Safety in Surgery, } 10\end{array}$ & $\begin{array}{l}\text { Prospectiv } \\
\text { e study } \\
\text { SORT } \\
\text { level } 1 \text { A }\end{array}$ & $\mathrm{N}-70$ & $\begin{array}{l}\text { The } \\
\text { utilization of } \\
\text { checklist } \\
\text { specifically }\end{array}$ & none & $\begin{array}{l}\text { Distinguishes } \\
\text { and describe } \\
\text { factors that } \\
\text { drive team }\end{array}$ & $\begin{array}{l}\text { The } \\
\text { utilization of } \\
\text { checklist } \\
\text { enables staff }\end{array}$ \\
\hline
\end{tabular}




\begin{tabular}{|c|c|c|c|c|c|c|}
\hline $\begin{array}{l}\text { Retrieved from } \\
\text { https://search.proquest.com/docview/1774002401 } \\
\text { ?accountid=158603 }\end{array}$ & & & $\begin{array}{l}\text { the Surgical } \\
\text { Safety } \\
\text { Checklist } \\
\text { (SSC) to } \\
\text { enhance } \\
\text { communicati } \\
\text { ons. }\end{array}$ & & $\begin{array}{l}\text { cooperation in } \\
\text { safety checks in } \\
\text { surgery. }\end{array}$ & \begin{tabular}{|l} 
to identify \\
deficits and \\
discrepancie \\
s for \\
accuracy of \\
patient \\
information, \\
thus \\
preventing \\
errors. \\
\end{tabular} \\
\hline $\begin{array}{l}\text { Hazelton, J.P, Ofe, E.C, Colacion, A.M, Hunter, K, } \\
\text { Caprano-Wehrle, L.M, Lachant, M.T.., \& } \\
\text { Seamon, M.J. (2015). The impact of a } \\
\text { multidisciplinary safety checklist on adverse } \\
\text { procedural events bedside bronchoscopy-guided } \\
\text { percutaneous tracheostomy. Journal of Trauma } \\
\text { Acute Care Surgery, 79(1): 111-116. } \\
\text { doi:10.1097/TA.0000000000000700 }\end{array}$ & $\begin{array}{l}\text { Prospectiv } \\
\text { e study } \\
\text { design } \\
\text { SORT } \\
\text { Level } 1 \text { A }\end{array}$ & $\mathrm{N}-247$ & $\begin{array}{l}\text { The } \\
\text { utilization of } \\
\text { multidiscipli } \\
\text { nary safety } \\
\text { checklist } \\
\text { before } \\
\text { bedside } \\
\text { bronchoscop } \\
\text { y-guided } \\
\text { percutaneous } \\
\text { tracheostomy } \\
\text { insertions } \\
\text { (BPTIs). }\end{array}$ & None & $\begin{array}{l}\text { The outcomes } \\
\text { recommend that } \\
\text { the } \\
\text { implementation } \\
\text { of a } \\
\text { multidisciplinar } \\
\text { y safety } \\
\text { checklist like } \\
\text { those utilized in } \\
\text { the OR would } \\
\text { benefit patients } \\
\text { during invasive } \\
\text { bedside } \\
\text { procedures. }\end{array}$ & $\begin{array}{l}\text { The most } \\
\text { important } \\
\text { finding of } \\
\text { the study is } \\
\text { that after the } \\
\text { implementat } \\
\text { ion of a } \\
\text { multidiscipli } \\
\text { nary safety } \\
\text { checklist for } \\
\text { use during a } \\
\text { bedside } \\
\text { bronchoscop } \\
\text { y-guided } \\
\text { percutaneou } \\
\text { s } \\
\text { tracheostom } \\
\text { y, there is a } \\
\text { significant } \\
\text { reduction in } \\
\text { the } \\
\text { incidence of } \\
\text { procedural } \\
\text { complicatio } \\
\text { ns. }\end{array}$ \\
\hline
\end{tabular}




\begin{tabular}{|c|c|c|c|c|c|c|}
\hline $\begin{array}{l}\text { Huber, T., Brinkmann, F., Lim, S., Schröder, C., } \\
\text { Stekhoven, D., Marti, W., ... Egger, R. R. (2017). } \\
\text { Implementation of an IT-guided checklist to } \\
\text { improve the quality of medication history records } \\
\text { at hospital admission. International Journal of } \\
\text { Clinical Pharmacy, 39(6), 1312-1319. } \\
\text { doi:10.1007/s11096-017-0545-0 }\end{array}$ & $\begin{array}{l}\text { Prospectiv } \\
\text { e study } \\
\text { Sort Level } \\
2 \text { A }\end{array}$ & $\mathrm{N}-228$ & $\begin{array}{l}\text { To decrease } \\
\text { the balance } \\
\text { of patients } \\
\text { with at least } \\
\text { one } \\
\text { medication } \\
\text { discrepancy } \\
\text { in the } \\
\text { medication } \\
\text { history at } \\
\text { admission by } \\
\text { performing } \\
\text { an IT- } \\
\text { guided check } \\
\text { list. }\end{array}$ & None & $\begin{array}{l}\text { Out of } 415 \\
\text { admissions, } 228 \\
\text { patients that } \\
\text { satisfied the } \\
\text { inclusion } \\
\text { criteria were } \\
\text { enrolled in the } \\
\text { study, } 113 \\
\text { before and } 115 \\
\text { patients after } \\
\text { intervention. } \\
\text { After } \\
\text { intervention, } \\
\text { medication } \\
\text { discrepancies } \\
\text { diminished } \\
\text { from } 69.9 \text { to } \\
29.6 \% \text { ( } p< \\
0.0001) \text { of } \\
\text { patients, the } \\
\text { average } \\
\text { medication } \\
\text { discrepancy per } \\
\text { patient was } \\
\text { reduced from } \\
2.3 \text { to } 0.6 \text { ( } p< \\
0.0001) \text {, and the } \\
\text { standard error, } \\
\text { omission of a } \\
\text { regularly used } \\
\text { medication, was } \\
\text { decreased from } \\
76.4 \text { to } 44.1 \% \\
(p<0.001) \text {. } \\
\end{array}$ & $\begin{array}{l}\text { The } \\
\text { implementat } \\
\text { ion of the } \\
\text { IT-guided } \\
\text { checklist is } \\
\text { correlated } \\
\text { with a } \\
\text { significant } \\
\text { decrease in } \\
\text { medication } \\
\text { discrepancie } \\
\text { s at } \\
\text { admission } \\
\text { and possibly } \\
\text { improves } \\
\text { medication } \\
\text { safety for } \\
\text { the patient. }\end{array}$ \\
\hline $\begin{array}{l}\text { Kozusko, S. D., Elkwood, L., Gaynor, D., \& Chagares, } \\
\text { S. A. (2016). An innovative approach to the } \\
\text { surgical time out: A patient-focused model: The }\end{array}$ & $\begin{array}{l}\text { Retrospect } \\
\text { ive design }\end{array}$ & N-998 & $\begin{array}{l}\text { The usage of } \\
\text { checklist that } \\
\text { involves }\end{array}$ & None & $\begin{array}{l}\text { The } \\
\text { development of } \\
\text { unique surgical }\end{array}$ & $\begin{array}{l}\text { Since the } \\
\text { utilization of } \\
\text { the }\end{array}$ \\
\hline
\end{tabular}




\begin{tabular}{|c|c|c|c|c|c|c|}
\hline $\begin{array}{l}\text { official voice of perioperative nursing the official } \\
\text { voice of perioperative nursing. AORN Journal, } \\
\text { 103(6), 617-622. doi:10.1016/j.aorn.2016.04.00 }\end{array}$ & \begin{tabular}{|l} 
SORT \\
level 1A
\end{tabular} & & $\begin{array}{l}\text { patient and } \\
\text { surgical team } \\
\text { that includes } \\
\text { preoperative, } \\
\text { pre-incision, } \\
\text { and } \\
\text { postoperative } \\
\text { time outs. }\end{array}$ & & $\begin{array}{l}\text { checklist with } \\
\text { the intention to } \\
\text { include patient } \\
\text { or family } \\
\text { member on pre- } \\
\text { operative } \\
\text { timeout } \\
\text { process. }\end{array}$ & $\begin{array}{l}\text { checklist, } \\
\text { there have } \\
\text { been zero } \\
\text { errors and } \\
\text { zero wrong- } \\
\text { site } \\
\text { surgeries. } \\
\text { Patients } \\
\text { verbalized } \\
\text { satisfaction } \\
\text { with their } \\
\text { inclusion in } \\
\text { the } \\
\text { preoperative } \\
\text { time out. }\end{array}$ \\
\hline $\begin{array}{l}\text { Lai, Y. H., Anderson, M. R., Weinberg, A. D., \& } \\
\text { Rosenblatt, M. A. (2015). Positive perceptions on } \\
\text { safety and satisfaction during a patient-centered } \\
\text { timeout before peripheral nerve blockade. } \\
\text { Journal of Clinical Anesthesia, 27(3), 214-220. } \\
\text { doi:10.1016/j.jclinane.2014.10.009 }\end{array}$ & $\begin{array}{l}\text { Qualitative/ } \\
\text { survey } \\
\text { single } \\
\text { research } \\
\text { study } \\
\text { SORT } \\
\text { Level 1A }\end{array}$ & $\mathrm{N}-200$ & $\begin{array}{l}\text { A } \\
\text { postoperative } \\
\text { survey } \\
\text { assessing } \\
\text { patient } \\
\text { perception, } \\
\text { experience, } \\
\text { and } \\
\text { satisfaction } \\
\text { with the } \\
\text { anesthetic ti } \\
\text { meout } \\
\text { prior to } \\
\text { regional } \\
\text { anesthesia. }\end{array}$ & None & $\begin{array}{l}\text { Patient } \\
\text { perceptions of } \\
\text { trust and safety } \\
\text { in regional } \\
\text { anesthesia } \\
\text { providers were } \\
\text { intensified by a } \\
\text { preprocedural } \\
\text { timeout } \\
\text { process; thus } \\
\text { positive } \\
\text { attitudes are } \\
\text { associated with } \\
\text { an exemplified } \\
\text { perioperative } \\
\text { experience and } \\
\text { patient } \\
\text { satisfaction }\end{array}$ & $\begin{array}{l}\text { One } \\
\text { hundred } \\
\text { seventy-five } \\
\text { patients } \\
\text { (93\% } \\
\text { enrollment) } \\
\text { completed } \\
\text { the study. } \\
\text { More than } \\
90 \% \text { of } \\
\text { patients } \\
\text { reported } \\
\text { agreeing } \\
\text { strongly to } \\
\text { feeling safe, } \\
\text { confident, } \\
\text { relaxed, and } \\
\text { positive } \\
\text { about their } \\
\text { participation } \\
\text { in the block } \\
\text { timeout. }\end{array}$ \\
\hline
\end{tabular}




\begin{tabular}{|c|c|c|c|c|c|c|}
\hline & & & & & & \begin{tabular}{|l} 
These \\
sentiments \\
are \\
associated \\
with less \\
reported \\
perioperativ \\
e pain and \\
higher \\
overall \\
satisfaction
\end{tabular} \\
\hline $\begin{array}{l}\text { Lea, M., Barstad, I., Mathiesen, L., Mowe, M., \& } \\
\text { Molden, E. (2016). Effect of teaching and } \\
\text { checklist implementation on accuracy of } \\
\text { medication history recording at hospital } \\
\text { admission. International Journal of Clinical } \\
\text { Pharmacy, 38(1), 20-24. doi:10.1007/s11096- } \\
\text { 015-0218-9 }\end{array}$ & $\begin{array}{l}\text { Prospectiv } \\
\text { e and } \\
\text { Comparati } \\
\text { ve studies } \\
\text { SORT } \\
\text { Level } 1 \text { A }\end{array}$ & $\mathrm{N}-175$ & $\begin{array}{l}\text { The } \\
\text { utilization of } \\
\text { teaching and } \\
\text { checklist in } \\
\text { reduction } \\
\text { medication } \\
\text { discrepancies }\end{array}$ & None & $\begin{array}{l}\text { The potential } \\
\text { for improved } \\
\text { accuracy of } \\
\text { history taking } \\
\text { on admission } \\
\text { for medication } \\
\text { reconciliation }\end{array}$ & $\begin{array}{l}\text { Mandatory } \\
\text { teaching and } \\
\text { utilization of } \\
\text { checklist } \\
\text { during } \\
\text { medication } \\
\text { history } \\
\text { taking } \\
\text { improved } \\
\text { medication } \\
\text { discrepan- } \\
\text { cies. } \\
\end{array}$ \\
\hline $\begin{array}{l}\text { Ruggiero, J., Smith, J., Copeland, J., \& Boxer, B. (2015). } \\
\text { Discharge time out: An innovative nurse-driven } \\
\text { protocol for medication reconciliation. Medical } \\
\text { Surgical Nursing, 24(3), 165-172. Retrieved from } \\
\text { https://search.proquest.com/docview/1687988777?accou } \\
\text { ntid=158603 }\end{array}$ & $\begin{array}{l}\text { Retrospec- } \\
\text { tive } \\
\text { quality } \\
\text { improve- } \\
\text { ment } \\
\text { design, } \\
\text { peer } \\
\text { reviewed } \\
\text { SORT } \\
\text { Level } 1 \text { A }\end{array}$ & $\mathrm{N}-325$ & $\begin{array}{l}\text { Utilization of } \\
\text { discharge } \\
\text { timeout by } 2 \\
\text { nurses with a } \\
\text { checklist }\end{array}$ & $\begin{array}{l}\text { The discharge } \\
\text { time-out } \\
\text { process was } \\
\text { modeled after } \\
\text { the operative } \\
\text { time-out } \\
\text { processes }\end{array}$ & $\begin{array}{l}\text { Reduction of } \\
\text { medication } \\
\text { discrepancies }\end{array}$ & \begin{tabular}{|l} 
Decreased \\
of \\
medication \\
discrepan- \\
cies and \\
sustained \\
reduction \\
for 20 \\
months \\
*Improved \\
discharge
\end{tabular} \\
\hline
\end{tabular}




\begin{tabular}{|c|c|c|c|c|c|c|}
\hline & & & & & & $\begin{array}{l}\text { practice } \\
\text { time } \\
\text { *Improved } \\
\text { collaborativ } \\
\text { e effort } \\
\text { among team }\end{array}$ \\
\hline $\begin{array}{l}\text { Shear, T., Deshur, M., Avram, M. J., Greenberg, S. B., } \\
\text { Murphy, G. S., Ujiki, M., ,̈ Wijas, B. (2018). } \\
\text { Procedural timeout compliance is improved with } \\
\text { real-time clinical decision support. Journal of } \\
\text { Patient Safety, 14(3), 148-152.doi: } \\
\text { 10.1097/PTS.0000000000000185 }\end{array}$ & $\begin{array}{l}\text { Prospec- } \\
\text { tive, } \\
\text { observatio } \\
\text { nal } \\
\text { blinded } \\
\text { design } \\
\text { SORT } \\
\text { Level } 2 \text { A }\end{array}$ & 300 & $\begin{array}{l}\text { Using a } \\
\text { checklist of } \\
\text { items, one } \\
\text { observer } \\
\text { documented } \\
\text { compliance } \\
\text { with the } \\
\text { safety } \\
\text { checklist in } \\
\text { all } 3 \text { phases. }\end{array}$ & None & $\begin{array}{l}\text { Assess } \\
\text { compliance } \\
\text { with a } \\
\text { presurgical } \\
\text { safety checklist } \\
\text { before and after } \\
\text { the institution } \\
\text { of a surgical } \\
\text { flight board } \\
\text { displaying a } \\
\text { surgical } \\
\text { safety checklist } \\
\text { with embedded } \\
\text { real-time } \\
\text { clinical } \\
\text { decision } \\
\text { support (CDS). }\end{array}$ & $\begin{array}{l}\text { Using the } \\
\text { electronic } \\
\text { medical } \\
\text { record with } \\
\text { real-time } \\
\text { CDS } \\
\text { improves } \\
\text { compliance } \\
\text { with } \\
\text { presurgical } \\
\text { safety check } \\
\text { lists. }\end{array}$ \\
\hline $\begin{array}{l}\text { Singh, R., \& Zughaib, M. (2019). Timeout for contrast: } \\
\text { Using physician behavior modification to reduce } \\
\text { contrast in the catheterization laboratory. } \\
\text { Cardiology Research \& Practice, } 1-6 . \\
\text { doi: } 10.1155 / 2019 / 9238124\end{array}$ & $\begin{array}{l}\text { Retrospect } \\
\text { ive study } \\
\text { SORT } \\
\text { level 3A }\end{array}$ & 12118 & $\begin{array}{l}\text { * Utilization } \\
\text { of Timeout } \\
\text { and use of } \\
\text { checklist for } \\
\text { contrast in } \\
\text { the } \\
\text { catherization } \\
\text { * Added } \\
\text { preprocedur } \\
\text { al checklist } \\
\text { in } \\
\text { September- } \\
\text { October }\end{array}$ & None & $\begin{array}{l}\text { The study } \\
\text { appraised the } \\
\text { impact of a } \\
\text { simple } \\
\text { physician } \\
\text { behavioral } \\
\text { modification } \\
\text { tool on } \\
\text { contrast used } \\
\text { in procedures } \\
\text { in the }\end{array}$ & $\begin{array}{l}\text { Significant } \\
\text { reduction of } \\
\text { utilization of } \\
\text { radio } \\
\text { contrast by } \\
\text { provider } \\
\text { after the } \\
\text { usage of } \\
\text { revised } \\
\text { timeout } \\
\text { process } \\
\text { before }\end{array}$ \\
\hline
\end{tabular}




\begin{tabular}{|c|c|c|c|c|c|c|}
\hline & & & $\begin{array}{l}2013 \text { in the } \\
\text { form of } \\
\text { maximum } \\
\text { allowed } \\
\text { contrast for } \\
\text { the patient. }\end{array}$ & & $\begin{array}{l}\text { catheterization } \\
\text { laboratory. }\end{array}$ & catherization \\
\hline $\begin{array}{l}\text { Tainter, C. R., Nguyen, A. P., Pollock, K. A., O'Brien, } \\
\text { E., O., Lee, J., Schmidt, U., .. . Meier, A. (2018). } \\
\text { The impact of a daily "medication time out" in } \\
\text { the intensive care unit. Journal of Critical Care, } \\
\text { 43, 366-369. doi: } 10.1016 / \text { j.jcrc.2017.09.018 }\end{array}$ & $\begin{array}{l}\text { Quality } \\
\text { Improvem } \\
\text { ent design } \\
\text { Level 3 } \\
\text { SORT } \\
\text { A }\end{array}$ & 347 & $\begin{array}{l}\text { The } \\
\text { disciplinary } \\
\text { team will } \\
\text { conduct } \\
\text { timeout } \\
\text { process daily } \\
\text { with ICU } \\
\text { patient } \\
\text { utilizing the } \\
\text { medication } \\
\text { administratio } \\
\text { n. }\end{array}$ & none & $\begin{array}{l}\text { Structured } \\
\text { checklist-style } \\
\text { interventions } \\
\text { may help } \\
\text { prevent errors. }\end{array}$ & $\begin{array}{l}\text { Standard } \\
\text { daily } \\
\text { medication } \\
\text { time out } \\
\text { during ICU } \\
\text { rounds } \\
\text { reduced } \\
\text { medication } \\
\text { variances } \\
\text { and increase } \\
\text { medication } \\
\text { changes. }\end{array}$ \\
\hline $\begin{array}{l}\text { Weingessel, B., Haas, M., Vécsei, C., \& Vécsei- } \\
\text { Marlovits, P. V. (2017). Clinical risk } \\
\text { management - a 3-year experience of team } \\
\text { timeout in } 18081 \text { ophthalmic patients. Acta } \\
\text { Ophthalmologica, 95(2), e89-e94. doi: } \\
\text { 10.1111/aos.13155 }\end{array}$ & $\begin{array}{l}\text { Quality } \\
\text { improvem } \\
\text { ent study } \\
\text { SORT } \\
\text { Level } 2 \text { A }\end{array}$ & $\begin{array}{l}18,081 \\
\text { operativ } \\
\text { e cases }\end{array}$ & $\begin{array}{l}\text { The } \\
\text { utilization of } \\
\text { team timeout } \\
\text { method } \\
\text { reduces } \\
\text { errors and } \\
\text { improves } \\
\text { safety by } \\
\text { enhancing } \\
\text { team } \\
\text { communicati } \\
\text { on } \\
\text { *Involving } \\
\text { the patient } \\
\text { during the } \\
\text { timepoint }\end{array}$ & None & $\begin{array}{l}\text { Performed } \\
\text { eighteen } \\
\text { thousand and } \\
\text { eighty-one } \\
\text { surgeries in the } \\
\text { specified } \\
\text { period; Noted } \\
53 \text { cases of the } \\
\text { wrong side' and } \\
52 \text { cases of } \\
\text { wrong } \\
\text { intraocular lens. } \\
\text { Ninety-six near } \\
\text { misses } \\
\text { concerned the } \\
\text { patients' data }\end{array}$ & $\begin{array}{l}\text { The study } \\
\text { resulted in a } \\
\text { reduction of } \\
\text { near misses } \\
\text { after an } \\
\text { adaptation } \\
\text { phase } \\
\text { of } 3 \text { months. } \\
\text { *The usage } \\
\text { of team time } \\
\text { out has } \\
\text { improved } \\
\text { patient } \\
\text { safety with } \\
\text { little effort }\end{array}$ \\
\hline
\end{tabular}




\begin{tabular}{|c|c|c|c|c|c|c|}
\hline & & & $\begin{array}{l}\text { process when } \\
\text { patient is } \\
\text { able. }\end{array}$ & & $\begin{array}{l}\text { and } 38 \\
\text { concerned } \\
\text { documentation. }\end{array}$ & \\
\hline $\begin{array}{l}\text { Wetmore, D., Goldberg, A., Gandhi, N., Spivack, J., } \\
\text { McCormick, P., \& DeMaria, S. (2016). An } \\
\text { embedded checklist in the anesthesia information } \\
\text { management system improves pre-anesthetic } \\
\text { induction setup: A randomized controlled trial in a } \\
\text { simulation setting. BMJ Quality \& Safety, 25(10), } \\
\text { 739.dx.doi:10.1136/bmjqs-2015-004707 }\end{array}$ & $\begin{array}{l}\text { Randomiz } \\
\text { e } \\
\text { controlled } \\
\text { design } \\
\text { study } \\
\text { SORT } \\
\text { Level 1A }\end{array}$ & 38 & $\begin{array}{l}\text { Implementati } \\
\text { on of Pre- } \\
\text { anesthetic } \\
\text { Induction } \\
\text { Patient } \\
\text { Safety } \\
\text { (PIPS) } \\
\text { Checklist }\end{array}$ & None & $\begin{array}{l}\text { To determine } \\
\text { the efficiency } \\
\text { of the checklist } \\
\text { when imbedded } \\
\text { in the } \\
\text { institutional } \\
\text { Anesthesia } \\
\text { Information } \\
\text { Management } \\
\text { system (AIMS) } \\
\text { on the resident's } \\
\text { performance. }\end{array}$ & $\begin{array}{l}\text { The } \\
\text { utilization of } \\
\text { a checklist } \\
\text { improved } \\
\text { resident } \\
\text { performance } \\
\text { in a } \\
\text { simulated } \\
\text { environment } \\
\text {. }\end{array}$ \\
\hline
\end{tabular}


Appendix D

Summary of Systematic Review

\begin{tabular}{|c|c|c|c|c|c|c|c|}
\hline Citation & $\begin{array}{l}\text { Quality } \\
\text { Grade }\end{array}$ & Question & $\begin{array}{c}\text { Search } \\
\text { Strategy }\end{array}$ & $\begin{array}{l}\text { Inclusion } \\
\text { and } \\
\text { Exclusion } \\
\end{array}$ & $\begin{array}{c}\text { Data } \\
\text { Extraction } \\
\text { and Analysis } \\
\end{array}$ & $\begin{array}{c}\text { Key } \\
\text { findings }\end{array}$ & Recommendation \\
\hline $\begin{array}{l}\text { Gillespie, B. M., Withers, T. K., Lavin, J., } \\
\text { Gardiner, T., \& Marshall, A. P. } \\
\text { (2016). Factors that drive team } \\
\text { participation in surgical safety } \\
\text { checks: A prospective study. Patient } \\
\text { Safety in Surgery, } 10 \text { Retrieved from } \\
\text { https://search.proquest.com/docview/ } \\
\text { 1774002401?accountid=158603 }\end{array}$ & $\begin{array}{l}\text { Prospective } \\
\text { study } \\
\text { SORT Level } \\
1 \text { A }\end{array}$ & $\begin{array}{l}\text { What is } \\
\text { importance } \\
\text { of checklist } \\
\text { in } \\
\text { preventing } \\
\text { errors? }\end{array}$ & $\begin{array}{l}\text { ProQuest } \\
\text { Complete } \\
\text { Word use: } \\
\text { Medical } \\
\text { Errors } \\
\text { AND } \\
\text { Timeout } \\
\text { AND } \\
\text { Checklist }\end{array}$ & $\begin{array}{l}\text { Inclusion } \\
: 2014- \\
2019 \\
\text { Date of } \\
\text { journal } \\
\text { and } \\
\text { Exclusio } \\
\text { n non- } \\
\text { English } \\
\text { Non- } \\
\text { human } \\
\text { samples }\end{array}$ & $\begin{array}{l}\text { Describe } \\
\text { factors that } \\
\text { drive team } \\
\text { cooperation } \\
\text { in safety } \\
\text { checks in } \\
\text { surgery. }\end{array}$ & $\begin{array}{l}\text { The } \\
\text { utilizatio } \\
\mathrm{n} \text { of } \\
\text { checklist } \\
\text { enables } \\
\text { staff to } \\
\text { identify } \\
\text { deficits } \\
\text { and } \\
\text { discrepan } \\
\text { cies for } \\
\text { accuracy } \\
\text { of patient } \\
\text { informati } \\
\text { on, thus } \\
\text { prevent } \\
\text { errors. }\end{array}$ & $\begin{array}{l}\text { The importance } \\
\text { of checklist in } \\
\text { preventing } \\
\text { errors. }\end{array}$ \\
\hline $\begin{array}{l}\text { Gao, M. C., Martin, P. B., Motal, J., Gingras, } \\
\text { L. F., Chai, C., Maikoff, M. E., ,Ä } \\
\text { Eiss, B. M. (2018). A } \\
\text { multidisciplinary discharge timeout } \\
\text { checklist improves patient education } \\
\text { and captures discharge process errors. } \\
\text { Quality Management in Health Care, } \\
\text { 27(2), 63-68. } \\
\text { doi:10.1097/QMH.000000000000016 } \\
8\end{array}$ & $\begin{array}{l}\text { Quality } \\
\text { improvemen } \\
\text { t design } \\
\text { SORT Level } \\
\text { 1A }\end{array}$ & $\begin{array}{l}\text { Does } \\
\text { discharge } \\
\text { time out } \\
\text { checklist } \\
\text { impacts } \\
\text { preventable } \\
\text { medical } \\
\text { errors? }\end{array}$ & $\begin{array}{l}\text { Not } \\
\text { Mentioned }\end{array}$ & $\begin{array}{l}\text { Inclusion } \\
\text { : Patient } \\
\text { discharge } \\
\text { d from } \\
\text { March } 1 \text {, } \\
2015 \text { to } \\
\text { Septembe } \\
\text { r } 16, \\
2015\end{array}$ & $\begin{array}{l}\text { Utilizing a } \\
\text { PDSA cycle } \\
\text { methodology } \\
\text { for checklist } \\
\text { and timeout } \\
\text { process. } \\
\text { *Completed } \\
\text { discharged } \\
\text { timeout } \\
\text { checklist } \\
\text { forms were } \\
\text { collected and }\end{array}$ & $\begin{array}{l}\text { Discharg } \\
\text { e time } \\
\text { out } \\
\text { stemmed } \\
\text { in } 24 \\
\text { changes } \\
\text { to } \\
\text { discharge } \\
\text { notes and } \\
\text { document } \\
\text { ation and } \\
1 \text { good }\end{array}$ & $\begin{array}{l}\text { Discharge time } \\
\text { out stemmed in } \\
24 \text { changes to } \\
\text { discharge notes } \\
\text { and } \\
\text { documentation } \\
\text { and } 1 \text { good catch } \\
\text { potential adverse } \\
\text { event. } \\
* 18 \text { out of } 24 \\
\text { changes in } \\
\text { discharge plan }\end{array}$ \\
\hline
\end{tabular}




\begin{tabular}{|c|c|c|c|c|c|c|c|}
\hline & & & & & $\begin{array}{l}\text { matched to } \\
\text { the master } \\
\text { discharge } \\
\text { log. } \\
\text { *Statistics } \\
\text { performed } \\
\text { using R } \\
\text { version3.3. } \\
\text { using P value } \\
\text { listed as } 2 \\
\text { tailed z test } \\
\text { independent } \\
\text { proportions. }\end{array}$ & $\begin{array}{l}\text { catch } \\
\text { potential } \\
\text { adverse } \\
\text { event. } \\
* 18 \text { out } \\
\text { of } 24 \\
\text { changes } \\
\text { in } \\
\text { discharge } \\
\text { plan were } \\
\text { medicatio } \\
\mathrm{n} \\
\text { reconcilia } \\
\text { tion } \\
\text { issues. } \\
* \text { Five } \\
\text { issues } \\
\text { caught in } \\
\text { follow up } \\
\text { appointm } \\
\text { ent. } \\
* \\
\text { Average } \\
\text { time to } \\
\text { complete } \\
\text { the } \\
\text { discharge } \\
\text { time out } \\
\text { was } 9.9 \\
\text { minutes. }\end{array}$ & $\begin{array}{l}\text { were medication } \\
\text { reconciliation } \\
\text { issues. } \\
\text { * Five issues } \\
\text { caught in follow } \\
\text { up appointment. } \\
* \text { Average time } \\
\text { to complete the } \\
\text { discharge time } \\
\text { out was } 9.9 \\
\text { minutes. }\end{array}$ \\
\hline $\begin{array}{l}\text { Hazelton, J.P, Ofe, E.C, Colacion, A.M, } \\
\text { Hunter, K, Caprano-Wehrle, L.M, } \\
\text { Lachant, M.T.., \& Seamon, M.J. } \\
\text { (2015). The impact of a } \\
\text { multidisciplinary safety checklist on } \\
\text { adverse procedural events bedside } \\
\text { bronchoscopy-guided percutaneous }\end{array}$ & $\begin{array}{l}\text { Prospective } \\
\text { study design } \\
\text { SORT Level } \\
1 \mathrm{~A}\end{array}$ & $\begin{array}{l}\text { Is the usage } \\
\text { of } \\
\text { multidiscip } \\
\text { linary } \\
\text { safety } \\
\text { checklist } \\
\text { before }\end{array}$ & $\begin{array}{l}\text { Not } \\
\text { identified } \\
\text { in the } \\
\text { study }\end{array}$ & $\begin{array}{l}\text { *Inclusio } \\
\mathrm{n} \\
\text { Patients } \\
\text { with } \\
\text { BPTI } \\
\text { pre- } \\
\text { interventi }\end{array}$ & $\begin{array}{l}* \mathrm{~A} p<0.05 \\
\text { was } \\
\text { considered } \\
\text { significant } \\
\text { for the study. }\end{array}$ & $\begin{array}{l}\text { After } \\
\text { impleme } \\
\text { ntation of } \\
\text { the } \\
\text { multidisc } \\
\text { iplinary } \\
\text { checklist, }\end{array}$ & $\begin{array}{l}\text { Multidisciplinary } \\
\text { safety checklist } \\
\text { tool and time out } \\
\text { procedure used } \\
\text { in OR would } \\
\text { benefit during }\end{array}$ \\
\hline
\end{tabular}




\begin{tabular}{|c|c|c|c|c|c|c|c|}
\hline $\begin{array}{l}\text { tracheostomy. Journal of Trauma } \\
\text { Acute Care Surgery, 79(1): 111-116. } \\
\text { doi:10.1097/TA.000000000000070 }\end{array}$ & & $\begin{array}{l}\text { bedside } \\
\text { bronchosco } \\
\text { py-guided } \\
\text { percutaneo } \\
\text { us } \\
\text { tracheosto } \\
\text { my } \\
\text { insertions } \\
\text { (BPTIs) } \\
\text { reduce } \\
\text { adverse } \\
\text { procedural } \\
\text { events? }\end{array}$ & & $\begin{array}{l}\text { on and } \\
\text { post } \\
\text { interventi } \\
\text { on. } \\
\text { Patient } \\
\text { with } \\
\text { difficulty } \\
\text { of } \\
\text { breathing } \\
\text { interventi } \\
\text { on } \\
\text { Exclusio } \\
\text { n: Patient } \\
\text { younger } \\
\text { than 16 } \\
\text { years old, } \\
\text { tracheost } \\
\text { omy } \\
\text { patients; } \\
\text { mandibul } \\
\text { ar } \\
\text { fixation } \\
\text { or halo } \\
\text { cervical } \\
\text { stabilizati } \\
\text { on. } \\
* \text { Settings } \\
\text { ICCU } \\
\text { bedside } \\
\text { settings }\end{array}$ & & $\begin{array}{l}\text { there is } \\
\text { significan } \\
\mathrm{t} \text { decrease } \\
\text { in } \\
\text { procedur } \\
\text { al } \\
\text { complicat } \\
\text { ions }\end{array}$ & $\begin{array}{l}\text { invasive bedside } \\
\text { procedure. }\end{array}$ \\
\hline $\begin{array}{l}\text { Huber, T., Brinkmann, F., Lim, S., Schröder, } \\
\text { C., Stekhoven, D., Marti, W., ... } \\
\text { Egger, R. R. (2017). Implementation } \\
\text { of an IT-guided checklist to improve } \\
\text { the quality of medication history } \\
\text { records at hospital admission. }\end{array}$ & $\begin{array}{l}\text { Prospective } \\
\text { study } \\
\text { Sort Level } 2 \\
\text { A }\end{array}$ & $\begin{array}{l}\text { Does } \\
\text { applying IT } \\
\text { guided } \\
\text { checklist } \\
\text { reduce } \\
\text { medication }\end{array}$ & $\begin{array}{l}\text { Not } \\
\text { mentioned }\end{array}$ & $\begin{array}{l}\text { Inclusion } \\
\text { : Patient } \\
16 \text { years } \\
\text { old and } \\
\text { above. }\end{array}$ & $\begin{array}{l}\text { Pharmacist } \\
\text { utilized a } \\
\text { standard } \\
\text { structured } \\
\text { questionnaire }\end{array}$ & $\begin{array}{l}\text { *Medicat } \\
\text { ion } \\
\text { discrepan } \\
\text { cies } \\
\text { declined } \\
\text { from } 69.9\end{array}$ & $\begin{array}{l}\text { The usage of } \\
\text { checklist } \\
\text { in obtaining } \\
\text { history during } \\
\text { admission } \\
\text { significantly }\end{array}$ \\
\hline
\end{tabular}




\begin{tabular}{|c|c|c|c|c|c|c|c|}
\hline $\begin{array}{l}\text { International Journal of Clinical } \\
\text { Pharmacy, 39(6), 1312-1319. } \\
\text { doi:10.1007/s11096-017-0545- }\end{array}$ & & $\begin{array}{l}\text { error } \\
\text { occurrence } \\
\text { by } \\
\text { obtaining } \\
\text { accurate } \\
\text { information } \\
\text { on } \\
\text { admission? }\end{array}$ & & $\begin{array}{l}\text { *Exclusi } \\
\text { on: } \\
\text { Patient } \\
\text { who were } \\
\text { discharge } \\
\text { d from } \\
\text { the } \\
\text { hospital } \\
\text { within } 48 \\
\text { hours } \\
\text { *Settings } \\
\text { : Surgical } \\
\text { ward }\end{array}$ & $\begin{array}{l}\text { * Significant } \\
\text { level for } \\
\text { adjusted } p \\
\text { values was } \\
\text { set } 0.05 \\
\text { * Exact } \\
\text { Fischer test }\end{array}$ & $\begin{array}{l}\text { to } 29.9 \% \\
(\mathrm{p}<0.000 \\
1)\end{array}$ & $\begin{array}{l}\text { prevent } \\
\text { discrepancies in } \\
\text { history taking } \\
\text { promote safety. }\end{array}$ \\
\hline $\begin{array}{l}\text { Kozusko, S. D., Elkwood, L., Gaynor, D., \& } \\
\text { Chagares, S. A. (2016). An } \\
\text { innovative approach to the surgical } \\
\text { time out: A patient-focused model: } \\
\text { The official voice of perioperative } \\
\text { nursing the official voice of } \\
\text { perioperative nursing. AORN } \\
\text { Journal, 103(6), 617-622. doi: } \\
\text { 10.1016/j.aorn.2016.04.00 }\end{array}$ & $\begin{array}{l}\text { SORT level } \\
1 \mathrm{~A}\end{array}$ & $\begin{array}{l}\text { Is the } \\
\text { application } \\
\text { of } \\
\text { presurgical, } \\
\text { precision } \\
\text { and post- } \\
\text { surgical } \\
\text { checklist } \\
\text { and time } \\
\text { out reduce } \\
\text { medical } \\
\text { errors? }\end{array}$ & $\begin{array}{l}\text { Not } \\
\text { mentioned }\end{array}$ & $\begin{array}{l}\text { Not } \\
\text { mentione } \\
\text { d } \\
\text { Setting: } \\
\text { operating } \\
\text { room- } \\
\text { hospital } \\
\text { setting. }\end{array}$ & $\begin{array}{l}\text { In } 2011, \\
4453 \\
\text { procedures } \\
\text { have used } \\
\text { pre- } \\
\text { operative, } \\
\text { pre-incision } \\
\text { timeouts,998 } \\
\text { have used all } \\
\text { three - there } \\
\text { are xero } \\
\text { discrepancies } \\
\text { and zero } \\
\text { wrong site } \\
\text { surgeries }\end{array}$ & $\begin{array}{l}\text { Impleme } \\
\text { nting } \\
\text { three } \\
\text { phases of } \\
\text { timeout } \\
\text { and } \\
\text { checklist } \\
\text { pre, } \\
\text { during } \\
\text { and post- } \\
\text { surgery } \\
\text { yielded } \\
\text { xero } \\
\text { discrepan } \\
\text { cies. }\end{array}$ & $\begin{array}{l}\text { Since the } \\
\text { utilization of the } \\
\text { checklist, there } \\
\text { have been zero } \\
\text { errors and zero } \\
\text { wrong-site } \\
\text { surgeries. } \\
\text { Patients } \\
\text { verbalized } \\
\text { satisfaction with } \\
\text { their inclusion in } \\
\text { the preoperative } \\
\text { time out. } \\
\text { *Frequent } \\
\text { timeout yields } \\
\text { zero medical } \\
\text { errors. }\end{array}$ \\
\hline $\begin{array}{l}\text { Lai, Y. H., Anderson, M. R., Weinberg, A. } \\
\text { D., \& Rosenblatt, M. A. (2015). } \\
\text { Positive perceptions on safety and } \\
\text { satisfaction during a patient-centered } \\
\text { timeout before peripheral nerve } \\
\text { blockade. Journal of Clinical }\end{array}$ & $\begin{array}{l}\text { Qualitative/ } \\
\text { survey } \\
\text { single } \\
\text { research } \\
\text { study }\end{array}$ & $\begin{array}{l}\text { Is post- } \\
\text { operative } \\
\text { survey } \\
\text { evaluating } \\
\text { patient } \\
\text { perception, }\end{array}$ & $\begin{array}{l}\text { Not } \\
\text { mentioned }\end{array}$ & $\begin{array}{l}\text { Inclusion } \\
\text { Orthoped } \\
\text { ic } \\
\text { patients } \\
\text { who will }\end{array}$ & $\begin{array}{l}\text { Spearman } \\
\text { and Pearson } \\
\text { correlation } \\
\text { statistics. P < } \\
0.05 \text { was } \\
\text { considered }\end{array}$ & $\begin{array}{l}\text { One } \\
\text { hundred } \\
\text { seventy- } \\
\text { five } \\
\text { patients } \\
(93 \%\end{array}$ & $\begin{array}{l}\text { Patient } \\
\text { perceptions of } \\
\text { trust and safety } \\
\text { in regional } \\
\text { anesthesia } \\
\text { providers were }\end{array}$ \\
\hline
\end{tabular}




\begin{tabular}{|c|c|c|c|c|c|c|}
\hline $\begin{array}{l}\text { Anesthesia, 27(3), 214-220. doi: } \\
\text { 10.1016/j.jclinane.2014.10.009 }\end{array}$ & $\begin{array}{l}\text { SORT1 } \\
\text { level A }\end{array}$ & $\begin{array}{l}\text { experience } \\
\text { and patient } \\
\text { satisfaction } \\
\text { with } \\
\text { anesthetic } \\
\text { timeout } \\
\text { before } \\
\text { regional } \\
\text { anesthesia } \\
\text { helps with } \\
\text { patient } \\
\text { confidence } \\
\text { and patient } \\
\text { perception } \\
\text { to safety? }\end{array}$ & $\begin{array}{l}\text { undergo } \\
\text { surgery } \\
\text { Exclusio } \\
\mathrm{n} \text { : } \\
\text { Emergen } \\
\text { cy } \\
\text { surgery, } \\
\text { patient } \\
\text { receiving } \\
\text { anxiolyti } \\
\text { c or } \\
\text { narcotic } \\
\text { medicatio } \\
\text { n within } \\
24 \text { hours } \\
\text { of } \\
\text { operation } \\
\text {; non- } \\
\text { speaking } \\
\text { English. } \\
\text { Setting: } \\
\text { Surgical } \\
\text { unit }\end{array}$ & $\begin{array}{l}\text { statistically } \\
\text { significant }\end{array}$ & $\begin{array}{l}\text { enrollme } \\
\text { nt) } \\
\text { complete } \\
\mathrm{d} \text { the } \\
\text { study. } \\
\text { More } \\
\text { than } 90 \% \\
\text { of } \\
\text { patients } \\
\text { reported } \\
\text { agreeing } \\
\text { strongly } \\
\text { to feeling } \\
\text { safe, } \\
\text { confident } \\
\text {, relaxed, } \\
\text { and } \\
\text { positive } \\
\text { about } \\
\text { their } \\
\text { participat } \\
\text { ion in the } \\
\text { block } \\
\text { timeout. } \\
\text { These } \\
\text { sentiment } \\
\text { s are } \\
\text { associate } \\
\text { d with } \\
\text { less } \\
\text { reported } \\
\text { periopera } \\
\text { tive pain } \\
\text { and } \\
\text { higher } \\
\text { overall } \\
\end{array}$ & $\begin{array}{l}\text { intensified by a } \\
\text { preprocedural } \\
\text { timeout process } \\
\text { thus positive } \\
\text { attitudes are } \\
\text { associated with } \\
\text { an exemplified } \\
\text { perioperative } \\
\text { experience and } \\
\text { patient } \\
\text { satisfaction }\end{array}$ \\
\hline
\end{tabular}




\begin{tabular}{|c|c|c|c|c|c|c|c|}
\hline & & & & & & $\begin{array}{l}\text { satisfacti } \\
\text { on }\end{array}$ & \\
\hline $\begin{array}{l}\text { Lea, M., Barstad, I., Mathiesen, L., Mowe, } \\
\text { M., \& Molden, E. (2016). Effect of } \\
\text { teaching and checklist } \\
\text { implementation on accuracy of } \\
\text { medication history recording at } \\
\text { hospital admission. International } \\
\text { Journal of Clinical Pharmacy, 38(1), } \\
\text { 20-24. doi:10.1007/s11096-015- } \\
\text { 0218-9 }\end{array}$ & $\begin{array}{l}\text { Prospective } \\
\text { and } \\
\text { Comparativ } \\
\text { e studies } \\
\text { SORT level } \\
1 \text { A }\end{array}$ & $\begin{array}{l}\text { Is checklist } \\
\text { necessary } \\
\text { to ensure } \\
\text { patient } \\
\text { safety? }\end{array}$ & $\begin{array}{l}\text { CINAHL } \\
\text { Complete: } \\
\text { Word use: } \\
\text { Patient } \\
\text { safety } \\
\text { AND } \\
\text { medicatio } \\
\text { n }\end{array}$ & $\begin{array}{l}\text { Inclusion } \\
\text { : patient } \\
\text { admitted } \\
\text { in } \\
\text { internal } \\
\text { medicine } \\
\text { ward }\end{array}$ & $\begin{array}{l}\text { Fischer's } \\
\text { exact test and } \\
\text { Mann- } \\
\text { Whitney test }\end{array}$ & $\begin{array}{l}\text { The } 60 \\
\text { out of } \\
119 \\
\text { patients } \\
(50.4 \%) \\
\text { in p2-the } \\
\text { checklist } \\
\text { was used } \\
\text { and only } \\
8 \text { patients } \\
\text { (6.7) } \\
\text { stayed } \\
\text { during } \\
\text { the entire } \\
\text { hospital } \\
\text { stay. }\end{array}$ & $\begin{array}{l}\text { Patient } \\
\text { perceptions of } \\
\text { trust and safety } \\
\text { in regional } \\
\text { anesthesia } \\
\text { providers were } \\
\text { intensified by a } \\
\text { preprocedural } \\
\text { timeout process } \\
\text { thus positive } \\
\text { attitudes are } \\
\text { associated with } \\
\text { an exemplified } \\
\text { perioperative } \\
\text { experience and } \\
\text { patient } \\
\text { satisfaction }\end{array}$ \\
\hline $\begin{array}{l}\text { Ruggiero, J., Smith, J., Copeland, J., \& } \\
\text { Boxer, B. (2015). Discharge time out: } \\
\text { An innovative nurse-driven protocol } \\
\text { for medication reconciliation. } \\
\text { Medical Surgical Nursing, 24(3), } \\
\text { 165-172. }\end{array}$ & $\begin{array}{l}\text { Retrospectiv } \\
\text { e quality } \\
\text { improvemen } \\
\text { t design, } \\
\text { peer } \\
\text { reviewed } \\
\text { SORT level } \\
1 \text { A }\end{array}$ & $\begin{array}{l}\text { What is the } \\
\text { importance } \\
\text { of Timeout } \\
\text { in } \\
\text { medication } \\
\text { reconciliati } \\
\text { on? }\end{array}$ & $\begin{array}{l}\text { Utilized } \\
\text { Ovid The } \\
\text { Medline, } \\
\text { CINAHL } \\
\text { PubMed } \\
\text { and } \\
\text { Cochrane } \\
\text { Database } \\
\text { of } \\
\text { systematic } \\
\text { Review } \\
\text { from } \\
2005- \\
2012\end{array}$ & $\begin{array}{l}\text { Inclusion } \\
: \\
\text { Adult } \\
\text { patients }\end{array}$ & $\begin{array}{l}\text { None } \\
\text { mentioned } \\
\text { The usage of } \\
\text { Timeout } \\
\text { reduced } \\
\text { medication } \\
\text { discrepancies } \\
\text {. }\end{array}$ & $\begin{array}{l}\text { medicatio } \\
\mathrm{n} \\
\text { discrepan } \\
\text { cies and } \\
\text { sustained } \\
\text { reduction } \\
\text { for } 20 \\
\text { months } \\
\text { *Improve } \\
\mathrm{d} \\
\text { discharge } \\
\text { practice } \\
\text { time } \\
\text { *Improve } \\
\mathrm{d} \\
\text { collabora }\end{array}$ & $\begin{array}{l}* \text { The usage of } \\
\text { Timeout reduced } \\
\text { medication } \\
\text { discrepancies. }\end{array}$ \\
\hline
\end{tabular}




\begin{tabular}{|c|c|c|c|c|c|c|c|}
\hline & & & & & & $\begin{array}{l}\text { tive effort } \\
\text { among } \\
\text { team }\end{array}$ & \\
\hline \multirow[t]{2}{*}{$\begin{array}{l}\text { Shear, T., Deshur, M., Avram, M. J., } \\
\text { Greenberg, S. B., Murphy, G. S., } \\
\text { Ujiki, M., ,Ä Wijas, B. (2018). } \\
\text { Procedural timeout compliance is } \\
\text { improved with real-time clinical } \\
\text { decision support. Journal of Patient } \\
\text { Safety, 14(3), 148-152. } \\
\text { doi:10.1097/PTS.0000000000000185 }\end{array}$} & $\begin{array}{l}\text { Prospective, } \\
\text { observation } \\
\text { al blinded } \\
\text { design } \\
\text { SORT level } \\
2 \text { A }\end{array}$ & $\begin{array}{l}\text { Is } \\
\text { embedded } \\
\text { presurgical } \\
\text { checklist in } \\
\text { clinical } \\
\text { decision } \\
\text { support } \\
\text { (CDS)impr } \\
\text { ove } \\
\text { compliance } \\
?\end{array}$ & $\begin{array}{l}\text { Not } \\
\text { mentioned }\end{array}$ & $\begin{array}{l}\text { Inclusion } \\
: \text { Ten } \\
\text { surgeons } \\
\text { from six } \\
\text { surgical } \\
\text { specialtie } \\
\text { s } \\
\text { Setting: } \\
\text { Surgical } \\
\text { unit }\end{array}$ & $\begin{array}{l}\text { Friedman } \\
\text { Test }\end{array}$ & $\begin{array}{l}\text { Utilizing } \\
\text { the } \\
\text { electronic } \\
\text { medical } \\
\text { record } \\
\text { with real- } \\
\text { time CDS } \\
\text { enhance } \\
\text { complian } \\
\text { ce with } \\
\text { presurgic } \\
\text { al } \\
\text { safety ch } \\
\text { ecklists. }\end{array}$ & $\begin{array}{l}\text { Assess } \\
\text { compliance with } \\
\text { a presurgical } \\
\text { safety checklist b } \\
\text { efore and after } \\
\text { the institution of } \\
\text { a surgical flight } \\
\text { board displaying } \\
\text { a surgical } \\
\text { safety checklist } \\
\text { with embedded } \\
\text { real-time clinical } \\
\text { decision support } \\
\text { (CDS). }\end{array}$ \\
\hline & $\begin{array}{l}\text { Randomize } \\
\text { controlled } \\
\text { design study } \\
\text { SORT level } \\
\text { 1A }\end{array}$ & $\begin{array}{l}\text { Is the } \\
\text { embedded } \\
\text { checklist in } \\
\text { the } \\
\text { Anesthesia } \\
\text { information } \\
\text { Manageme } \\
\text { nt helps in } \\
\text { improving } \\
\text { performanc } \\
\text { e among } \\
\text { Anesthesiol } \\
\text { ogy } \\
\text { residents }\end{array}$ & $\begin{array}{l}\text { Non- } \\
\text { mentioned }\end{array}$ & $\begin{array}{l}\text { Inclusion } \\
: \\
* 49 \\
\text { residents } \\
\text { offered } \\
\text { but only } \\
38 \text { were } \\
\text { recruited. } \\
* \text { Both } \\
\text { male and } \\
\text { female } \\
\text { residents }\end{array}$ & $\begin{array}{l}\text { SAS system } \\
\text { software }\end{array}$ & $\begin{array}{l}\text { The data } \\
\text { reflected } \\
\text { a } \\
\text { statistical } \\
\text { ly } \\
\text { significan } \\
\text { t } \\
\text { differenc } \\
\text { e in } \\
\text { performa } \\
\text { nce of the } \\
\text { residents } \\
\text { when a } \\
\text { checklist } \\
\text { is } \\
\text { prompted }\end{array}$ & $\begin{array}{l}\text { The usage of } \\
\text { checklist can } \\
\text { improve } \\
\text { performance. }\end{array}$ \\
\hline $\begin{array}{l}\text { Singh, R., \& Zughaib, M. (2019). Timeout } \\
\text { for contrast: Using physician }\end{array}$ & $\begin{array}{l}\text { Retrospectiv } \\
\text { e study }\end{array}$ & $\begin{array}{l}\text { Is using } \\
\text { timeout for }\end{array}$ & $\begin{array}{l}\text { Non- } \\
\text { Mentioned }\end{array}$ & $\begin{array}{l}\text { Inclusion } \\
\text { : Patients } \\
\text { underwent }\end{array}$ & $\begin{array}{l}\text { None } \\
\text { mentioned }\end{array}$ & $\begin{array}{l}\text { Significa } \\
\text { nt }\end{array}$ & $\begin{array}{l}\text { The study } \\
\text { appraised the }\end{array}$ \\
\hline
\end{tabular}




\begin{tabular}{|c|c|c|c|c|c|c|c|}
\hline $\begin{array}{l}\text { behavior modification to reduce } \\
\text { contrast in the catheterization } \\
\text { laboratory. Cardiology Research \& } \\
\text { Practice, } 1-6 \text {. } \\
\text { doi:10.1155/2019/9238124 }\end{array}$ & $\begin{array}{l}\text { SORT level } \\
3 \mathrm{~A}\end{array}$ & $\begin{array}{l}\text { contrast } \\
\text { use before } \\
\text { cardiac } \\
\text { catherizatio } \\
\text { n reduce } \\
\text { the usage } \\
\text { of radio } \\
\text { contrast? }\end{array}$ & & $\begin{array}{l}\text { procedure } \\
\text { in cardiac } \\
\text { Cath } \\
\text { erization } \\
\text { from } \\
\text { January } \\
2013 \text { to } \\
\text { August } \\
201 \text { y6 }\end{array}$ & & $\begin{array}{l}\text { reduction } \\
\text { of } \\
\text { utilizatio } \\
\mathrm{n} \text { of radio } \\
\text { contrast } \\
\text { by } \\
\text { provider } \\
\text { after the } \\
\text { usage of } \\
\text { revised } \\
\text { timeout } \\
\text { process } \\
\text { before } \\
\text { catherizat } \\
\text { ion }\end{array}$ & $\begin{array}{l}\text { impact of a } \\
\text { simple physician } \\
\text { behavioral } \\
\text { modification tool } \\
\text { on contrast used } \\
\text { in procedures in } \\
\text { the } \\
\text { catheterization } \\
\text { laboratory using } \\
\text { timeout prior to } \\
\text { catherization. }\end{array}$ \\
\hline $\begin{array}{l}\text { Tainter, C. R., Nguyen, A. P., Pollock, K. A., } \\
\text { O'Brien, E., O., Lee, J., Schmidt, U., . } \\
\text { Meier, A. (2018). The impact of a } \\
\text { daily “medication time out" in the } \\
\text { intensive care unit. Journal of Critical } \\
\text { Care, 43, 366-369. doi: } \\
\text { 10.1016/j.jcrc.2017.09.018 }\end{array}$ & $\begin{array}{l}\text { Quality } \\
\text { Improveme } \\
\text { nt design } \\
\text { Level } 3 \\
\text { SORT } \\
\text { A }\end{array}$ & $\begin{array}{l}\text { What is the } \\
\text { effect of } \\
\text { "Time out" } \\
\text { in } \\
\text { medication } \\
\text { reconciliati } \\
\text { on? }\end{array}$ & & $\begin{array}{l}\text { Inclusion: } \\
\text { Period; } \\
\text { November } \\
\text { 2015- } \\
\text { February } \\
\text { 2016- ICU } \\
\text { patients. } \\
\text { Settings:1 } \\
2 \text { bed } \\
\text { surgical } \\
\text { intensive } \\
\text { care units }\end{array}$ & $\begin{array}{l}\text { None } \\
\text { mentioned }\end{array}$ & $\begin{array}{l}\text { Standard } \\
\text { daily } \\
\text { medicatio } \\
\text { n "time } \\
\text { out" } \\
\text { during } \\
\text { ICU } \\
\text { rounds } \\
\text { reduced } \\
\text { medicatio } \\
\text { n } \\
\text { variances } \\
\text { and } \\
\text { increase } \\
\text { medicatio } \\
\text { n } \\
\text { changes. }\end{array}$ & $\begin{array}{l}\text { The utilization of } \\
\text { time out on } \\
\text { medication } \\
\text { reconciliation } \\
\text { reduce or } \\
\text { prevent errors } \\
\text { and promote } \\
\text { patient safety. }\end{array}$ \\
\hline $\begin{array}{l}\text { Weingessel, B., Haas, M., Vécsei, C., \& } \\
\text { Vécsei-Marlovits, P. V. (2017). } \\
\text { Clinical risk management - a 3-year } \\
\text { experience of team timeout in } 18081\end{array}$ & $\begin{array}{l}\text { Quality } \\
\text { improvement } \\
\text { study } \\
\text { SORT level } 2 \\
\text { A }\end{array}$ & $\begin{array}{l}\text { Is } \\
\text { utilization } \\
\text { of team } \\
\text { timeout }\end{array}$ & $\begin{array}{l}\text { Non- } \\
\text { mentioned }\end{array}$ & $\begin{array}{l}\text { Non- } \\
\text { mentioned }\end{array}$ & $\begin{array}{l}\text { Standard } \\
\text { Welch t test } \\
\text { to compare }\end{array}$ & $\begin{array}{l}\text { Performed } \\
\text { Eighteen } \\
\text { thousand } \\
\text { and } \\
\text { eighty-one }\end{array}$ & $\begin{array}{l}\text { The study } \\
\text { resulted in a } \\
\text { reduction of near } \\
\text { misses was noted }\end{array}$ \\
\hline
\end{tabular}




\begin{tabular}{|c|c|c|c|c|c|c|c|}
\hline $\begin{array}{l}\text { ophthalmic patients. Acta } \\
\text { Ophthalmologica, 95(2), e89-e94. } \\
\text { doi:10.1111/aos.13155 }\end{array}$ & & $\begin{array}{l}\text { method } \\
\text { reducing } \\
\text { errors and } \\
\text { improve } \\
\text { safety by } \\
\text { enhancing } \\
\text { team } \\
\text { communica } \\
\text { tion? }\end{array}$ & & & $\begin{array}{l}\text { the relative } \\
\text { errors rates. } \\
\text { The test } \\
\text { resulted a } \\
\text { significantly } \\
\text { difference p } \\
\text { value of } \\
<0.001 \text {. }\end{array}$ & $\begin{array}{l}\text { surgeries } \\
\text { in the } \\
\text { specified } \\
\text { period; } \\
\text { Noted } 53 \\
\text { cases of } \\
\text { the wrong } \\
\text { sides and } \\
52 \text { cases } \\
\text { of wrong } \\
\text { intraocular } \\
\text { lens. } \\
\text { Ninety-six } \\
\text { near } \\
\text { misses } \\
\text { concerned } \\
\text { the } \\
\text { patients' } \\
\text { data and } \\
38 \\
\text { concerned } \\
\text { document } \\
\text { ation. }\end{array}$ & $\begin{array}{l}\text { after an } \\
\text { adaptation phase } \\
\text { of } 3 \text { months. } \\
\text { *The usage of } \\
\text { team time out } \\
\text { has improved } \\
\text { patient safety. }\end{array}$ \\
\hline $\begin{array}{l}\text { Wetmore, D., Goldberg, A., Gandhi, N., } \\
\text { Spivack, J., McCormick, P., \& } \\
\text { Demaria, S. (2016). An embedded } \\
\text { checklist in the anesthesia } \\
\text { information management system } \\
\text { improves pre-anesthetic induction } \\
\text { setup: A randomized controlled trial } \\
\text { in a simulation setting. BMJ Quality } \\
\text { \& Safety, 25(10), } \\
\text { 739.dx.doi:10.1136/bmjqs-2015- } \\
\text { 004707 }\end{array}$ & $\begin{array}{l}\text { Randomize } \\
\text { controlled } \\
\text { design study } \\
\text { SORT level } \\
\text { 1A }\end{array}$ & $\begin{array}{l}\text { Is the } \\
\text { embedded } \\
\text { checklist in } \\
\text { the } \\
\text { Anesthesia } \\
\text { information } \\
\text { Manageme } \\
\text { nt helps in } \\
\text { improving } \\
\text { performanc } \\
\text { e among } \\
\text { Anesthesiol } \\
\text { ogy } \\
\text { residents }\end{array}$ & $\begin{array}{l}\text { Non - } \\
\text { mentioned }\end{array}$ & $\begin{array}{l}\text { Inclusion } \\
* 49 \\
\text { residents } \\
\text { offered } \\
\text { but only } \\
38 \text { were } \\
\text { recruited. } \\
\text { *Both } \\
\text { male and } \\
\text { female } \\
\text { residents }\end{array}$ & $\begin{array}{l}\text { SAS system } \\
\text { software }\end{array}$ & $\begin{array}{l}\text { The data } \\
\text { reflected } \\
\text { a } \\
\text { statistical } \\
\text { ly } \\
\text { significan } \\
\text { t } \\
\text { differenc } \\
\text { e in } \\
\text { performa } \\
\text { nce of the } \\
\text { residents } \\
\text { when a } \\
\text { checklist }\end{array}$ & $\begin{array}{l}\text { The usage of } \\
\text { checklist can } \\
\text { improve } \\
\text { performance. }\end{array}$ \\
\hline
\end{tabular}




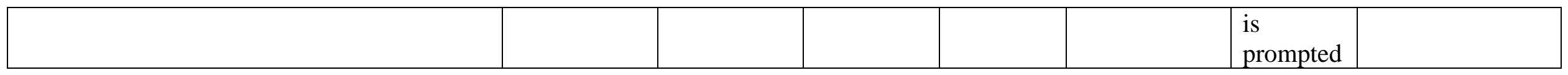


Appendix E

Project Schedule

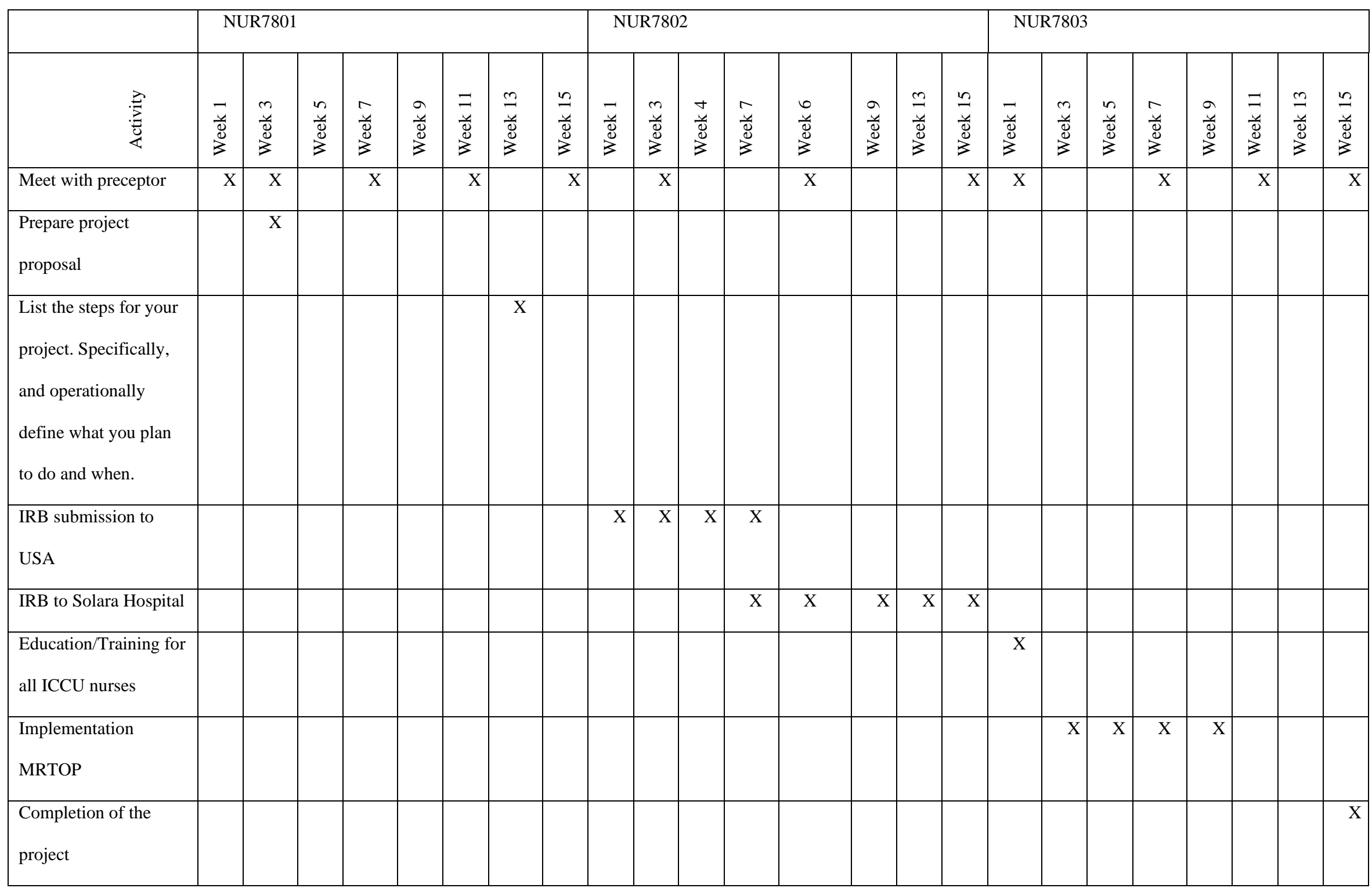




\begin{tabular}{|l|c|c|}
\hline \multicolumn{1}{|c}{} & \multicolumn{2}{c|}{ Appendix F } \\
\hline \multicolumn{1}{|c|}{ Projected Expenses } & Cost Analysis/Budget & \multicolumn{1}{c|}{ Miscellaneous } \\
\hline Educational Materials & Cost & MRTOP Brochures \\
\hline Printing / Handouts & 150.00 & \\
\hline Kaizen Event Meeting 4 hours & 200.00 & Posters, Flyers, and Pens \\
\hline Total Expenses & & $\begin{array}{c}\text { Team Leaders/ Champions and } \\
\text { Solara Leaders-Snacks and }\end{array}$ \\
\hline & & Supplies Needed in the Event \\
\hline
\end{tabular}


Appendix G

Medication Reconciliation Timeout Process Checklist

\section{Solara}

Specialty Hospitals

\section{Medication Reconciliation Timeout Process (MRTOP)} Checklist

1. All complete:

- Right Medication

Right Dose

Right Unit Measure

Right Route

Right Frequency

Right Indication PRN and Instructions

2. All Medications in the transfer form are transcribed in Solara admission order

3. Height and weight

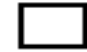

mary nurse

House supervisor 
Appendix $\mathrm{H}$

Data Analysis Table

\begin{tabular}{|c|c|c|}
\hline Variables & Type of Data & Statistical Test \\
\hline $\begin{array}{c}\text { Years of Experience } \\
(<3 \text { years, }>5 \text { years, } \\
>\text { 10years, }>20)\end{array}$ & Ordinal & Frequency, Percentage \\
\hline $\begin{array}{c}\text { Nurse Compliance } \\
\text { Medication Error } \\
\text { Pre and Post }\end{array}$ & Nominal & Frequency, Percentage \\
\hline $\begin{array}{c}\text { Education Background } \\
(\text { ADN, BSN, MSN) }\end{array}$ & Continuous & Unpaired t-test \\
\hline $\begin{array}{c}\text { Job Title (RN or LVN) } \\
\text { Gender (Female and } \\
\text { Male) }\end{array}$ & Nominal & Frequency, Percentage \\
\hline
\end{tabular}


Appendix I

PowerPoint Presentation
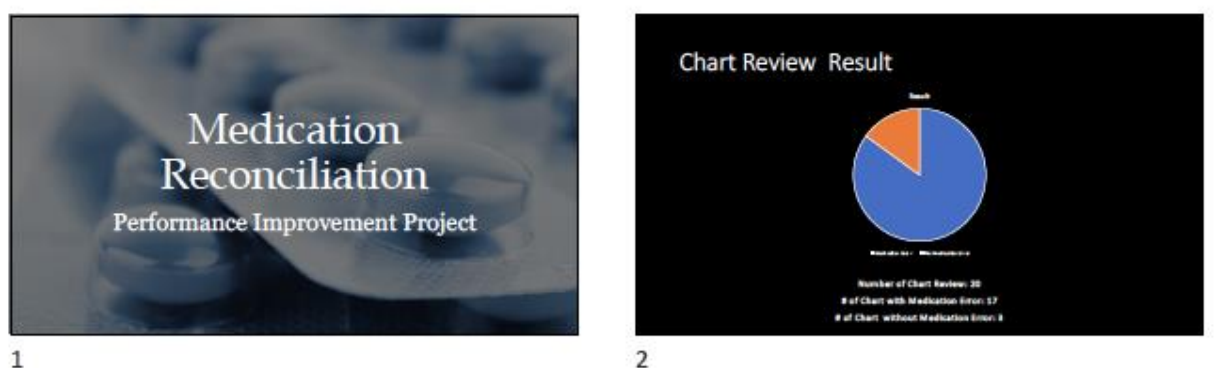

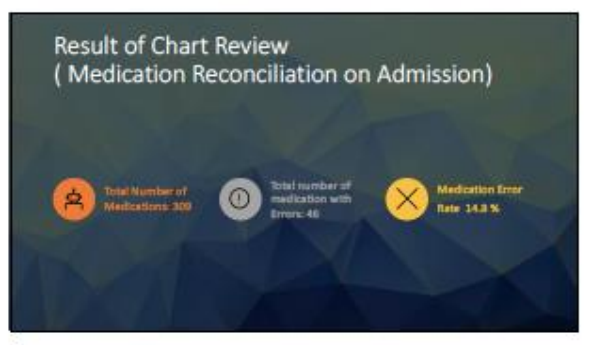

3

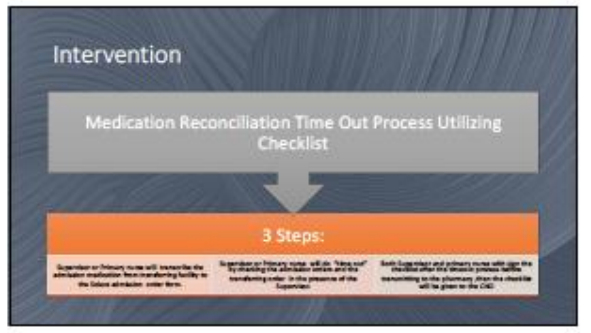

5

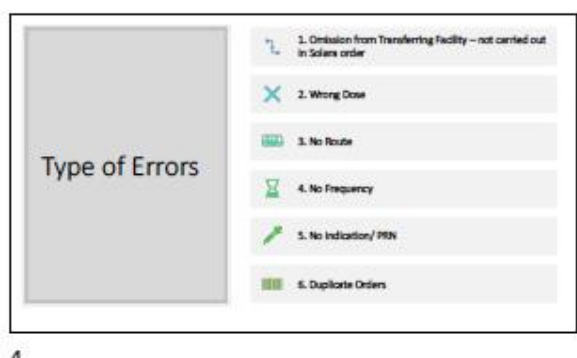

4

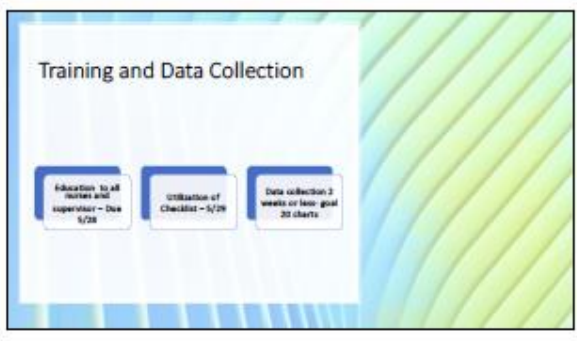

6 


\section{Appendix $\mathbf{J}$}

\section{USAHS Approval Letter}

|

University of St. Augustine for Health Sciences

Doctor of Nursing Practice Program

Evidence-Based Practice Review Council

1 University Blvd.

St. Augustine, FL 32086

$2 / 14 / 2020$

Dear Renante Dizon

Your proposal titled The Effect of Medication Reconciliation Timeout on Patient Safety: A Quality Improvement Project has been reviewed by the University of St. Augustine for Health Sciences Doctor of Nursing Practice Evidence-Based Practice Review Council (EPRC) and determined to:

meet the requirements for research as defined in the Federal Register. You must make adjustments to the proposal to reflect the DNP program requirements and resubmit for additional review. Work closely with your faculty member during this process.

X__ not meet the requirements for research as defined in the Federal Register. Your proposal reflects an evidence-based practice change project. The proposal must be implemented as submitted (changes are not permitted). You may proceed to obtain approvals from the facility where the project will be implemented. Implementation may not begin until you are notified in writing by faculty that you may implement the project.

Questions regarding the USAHS approval process should be addressed to Dr. Douglas Turner at DTurner@usa.edu. Questions regarding the facility approval process should be addressed to course faculty.

Sincerely,

Douglas Yutnet

Douglas M Turner, PhD, DNP, RN, CNE, NE-BC, NEA-BC 


\section{Appendix K}

Agency Approval Letter

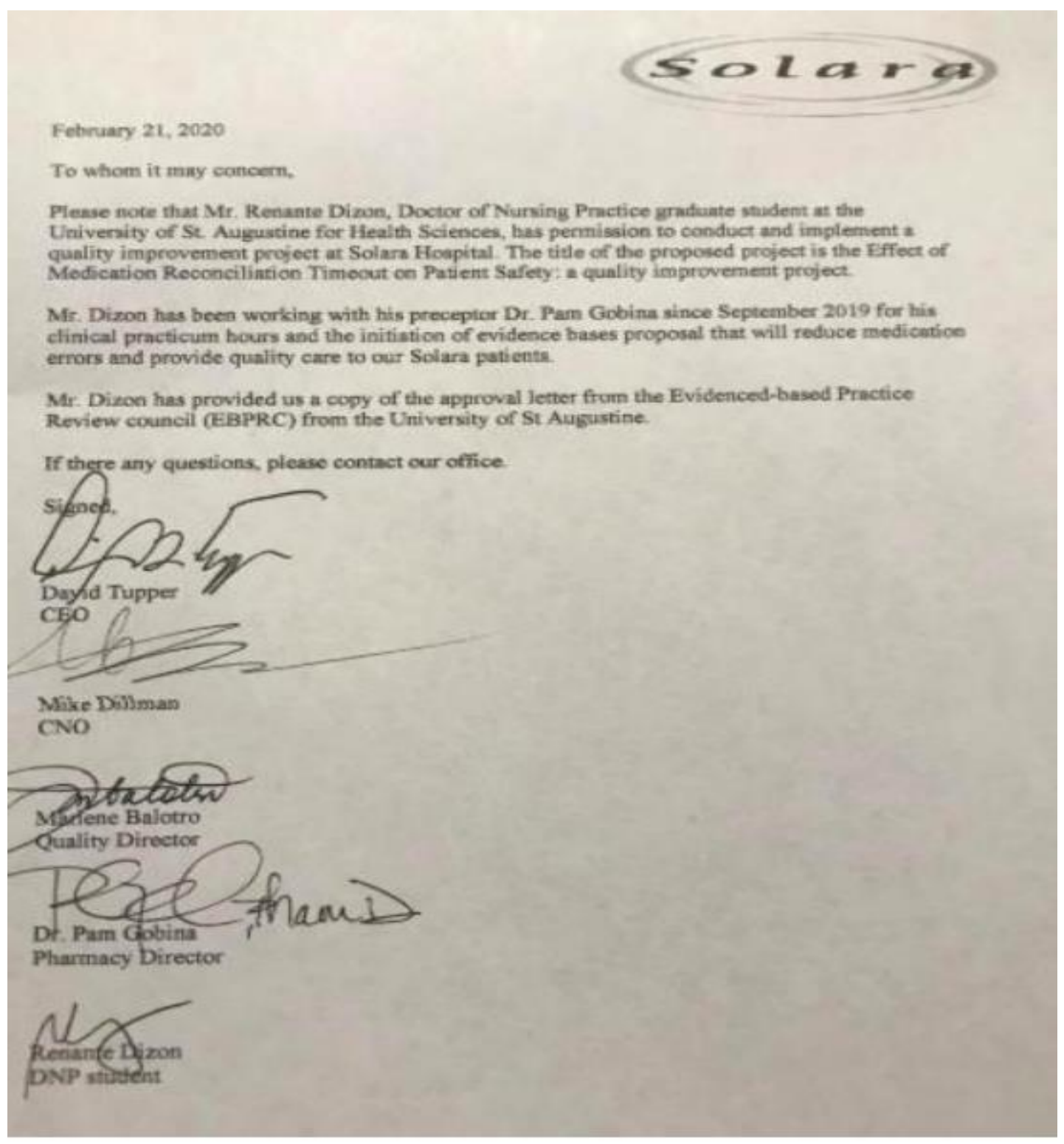

